\title{
Consumption of atmospheric methane in a limestone cave in Indiana, USA
}

Kevin D. Webster ${ }^{\text {* }}$, Anmar Mirza ${ }^{\mathrm{b}}$, Jessica M. Deli ${ }^{\mathrm{c}}$, Peter E. Sauer ${ }^{\mathrm{a}}$, Arndt Schimmelmann ${ }^{\mathrm{a}}$

a. Department of Geological Sciences, Indiana University, $1001 \mathrm{E} 10^{\text {th }}$ St. Bloomington, IN 47405 USA

b. National Coordinator National Cave Rescue Commission, 3430 Huron-Williams Rd, Williams, IN 47470 USA

c. Central Region Coordinator National Cave Rescue Commission, $200213^{\text {th }}$ St., Bedford, IN 47421 USA

*. Corresponding author. kevdwebs@indiana.edu

\begin{abstract}
Recent observations suggest that karst landscapes may be an unaccounted sink for atmospheric $\mathrm{CH}_{4}$, but questions remain about the processes contributing to sub-atmospheric $\mathrm{CH}_{4}$ mole fractions in caves. The $\mathrm{CH}_{4}$ dynamics associated with karst environments were studied over 18 months at 6 locations in Buckner Cave, Southern Indiana by measuring the mole fractions and stable isotopic composition of $\mathrm{CH}_{4}$ and carbon dioxide $\left(\mathrm{CO}_{2}\right) . \mathrm{CO}_{2}$ mole fractions were used to infer seasonal changes in airflow. Samples were obtained on a monthly basis. $\mathrm{CH}_{4}$ mole fractions ranged from $1.9 \pm 0.1 \mathrm{ppm}$ near the cave entrance to $0.1 \pm 0.1 \mathrm{ppm}$ in the more remote parts of the cave. The carbon and hydrogen stable isotopic compositions of $\mathrm{CH}_{4}$ in the cave ranged from -58.7 to $+7 \%$ (VPDB) and -170 to $+10 \%$ (VSMOW), respectively. The isotopic data suggest that the $\mathrm{CH}_{4}$ dynamics of Buckner Cave can be
\end{abstract}


described by a seasonally variable mixing system in which atmospheric $\mathrm{CH}_{4}$ enters primarily through the main entrance and is subsequently consumed by methanotrophs. Additionally, at least two smaller $\mathrm{CH}_{4}$ sources are evident when air has been stagnant. The results suggest that subterranean karst cavities are an important sink for atmospheric $\mathrm{CH}_{4}$.

Keywords: Cave air, Methane, Carbon Dioxide, Cave, Methanotrophy, Greenhouse Gas

\section{Introduction}

The rapidly increasing abundance of atmospheric methane $\left(\mathrm{CH}_{4}\right)$, a greenhouse gas, has been linked to anthropogenic activity (Craig and Chou, 1982; U.S. EPA, 2010; Ciais et al., 2013). Accurate climate forecasting requires a detailed understanding of $\mathrm{CH}_{4}$ sources and sinks affecting atmospheric abundances. Despite progress quantifying $\mathrm{CH}_{4}$ sources and sinks, the uncertainties of individual sources and sinks remain large (Kirschke et al., 2013). Major $\mathrm{CH}_{4}$ sources to the atmosphere include natural sources such as wetlands, freshwaters, and geologic emissions (seepage), as well as anthropogenic sources such as agriculture and fossil fuel use (Ciais et al., 2013). The major sink of atmospheric $\mathrm{CH}_{4}$ is oxidation by the hydroxyl radical $(\cdot \mathrm{OH})$ which accounts for $90 \%$ of the total losses, whereas oxidation by $\mathrm{CH}_{4}$ consuming (methanotrophic) microorganisms in soils is the next largest sink and accounts for about $2 \%$ of the losses (Naik et al., 2013; Dlugokencky et al., 2011). The advective flow of air through porous rock units, including karst, causes the atmosphere to interact with the subsurface which, if oxidizing agents are present, would aid in the removal of $\mathrm{CH}_{4}$ from the atmosphere. 
Karst landforms cover $10-20 \%$ of the continental surface (Palmer, 1991), and result from the interaction between soluble rock units and water. Mature karst landscapes exhibit solution-enlarged fractures, caves, and internal drainage networks which also provide conduits for atmospheric exchange (Atkinson et al., 1983; Gregorič et al., 2014). The surface area of the conduits capable of interacting with the atmosphere is unknown, in part because much of the surface area occurs in fractures that are too small for easy exploration (Curl, 1966). Despite the fact that some subsurface karst environments are inaccessible, the accessibility of caves provides a way to assess atmospheric exchange with the subsurface.

Limestone caves form as acidic water dissolves carbonate bedrock. Two common types are (1) epigenic caves, which form as meteoric water enriched in carbonic acid dissolves limestone, and (2) hypogenic caves, which form where deep-sourced waters, usually with sulfuric acid, migrate upwards. The different chemistry of the fluids entering these two types of caves also influences the paths of dissolved ions and gases, including $\mathrm{CH}_{4}$, into the cave. Subterranean measurements of $\mathrm{CH}_{4}$ mole fractions in karst air come from caves formed or forming from carbonic acid (epigenic speleogenesis) and those currently undergoing sulfuric acid speleogenesis (hypogenic). Epigenic caves dominate the total land area represented by karst and the $\mathrm{CH}_{4}$ dynamics of these caves are more representative of the typical biogeochemical conditions present in karst. $\mathrm{CH}_{4}$ mole fractions in the air of epigenic caves in Gibraltar, Spain, and Australia (Mattey et al., 2013; Fernandez-Cortes et al., 2015; McDonough et al., 2016) are generally below that of the atmospheric background of $1.8 \mathrm{ppm}$ (ppm, parts per million, is used to abbreviate $\mu \mathrm{mol} \mathrm{mol}{ }^{-1}$, dry air mole fraction) (Dlugokencky et al., 2003; Adushkin and Kudryavtsev, 2010; Dlugokencky et al., 2011). The observations of subatmospheric $\mathrm{CH}_{4}$ mole fractions in caves and karst have led to suggestions that they are 
functioning as $\mathrm{CH}_{4}$ sinks, however questions regarding the processes contributing to low $\mathrm{CH}_{4}$ mole fractions in caves remain. In contrast, $\mathrm{CH}_{4}$ mole fractions in the air of caves undergoing sulfuric acid speleogenesis have ranged from $3 \mathrm{ppm}$ to $1 \%$ by volume and have been reported from only three locations (Sarbu et al., 1996; Hutchens et al., 2004; Engel et al., 2004; Jones et al., 2012). These mole fractions are higher than the atmospheric background.

The sub-atmospheric $\mathrm{CH}_{4}$ mole fractions observed in the systems in Gibraltar Spain, and Australia were proposed to have been caused by different mechanisms. The mechanism put forward to explain low $\mathrm{CH}_{4}$ mole fractions in the Gibraltar cave relied on increases in $\delta^{13} \mathrm{C}_{\mathrm{CH}_{4}}$ values that coincided with decreasing $\mathrm{CH}_{4}$ mole fractions. These data fit a Rayleigh distillation model caused by methanotrophy (i.e., $\mathrm{CH}_{4}$ being consumed by microorganisms, Mattey et al., 2013). This hypothesis is supported by the observation of methanotrophs in other epigenic cave systems (Pašić et al., 2010; Porca et al., 2012; Ortiz et al., 2013; McDonough et al., 2016). In contrast, the low $\mathrm{CH}_{4}$ mole fractions observed in the air of Spanish caves were hypothesized to have been caused by radical reactions with $\mathrm{CH}_{4}$ that were initiated by the radioactive decay of radon (Fernandez-Cortes et al., 2015).

The stable isotopic ratios of ${ }^{13} \mathrm{C}$ to ${ }^{12} \mathrm{C}$ and of ${ }^{2} \mathrm{H}$ to ${ }^{1} \mathrm{H}$ in $\mathrm{CH}_{4}$ are known to reflect the process by which the $\mathrm{CH}_{4}$ was generated, and may help determine the sources and sinks of $\mathrm{CH}_{4}$ in caves. Atmospheric $\mathrm{CH}_{4}$ has $\delta^{13} \mathrm{C}_{\mathrm{CH}_{4}}$ and $\delta^{2} \mathrm{H}_{\mathrm{CH}_{4}}$ values near $-47 \%$ and $-100 \%$, respectively (Miller et al., 2002; Townsend-Small et al., 2012). Microorganisms produce $\mathrm{CH}_{4}$ through two major pathways, carbonate reduction and acetoclastic methanogenesis; the $\mathrm{CH}_{4}$ produced by both of these pathways is enriched in light isotopologues (Whiticar, 1999). $\mathrm{CH}_{4}$ generated from carbonate reduction is characterized by $\delta^{13} \mathrm{C}_{\mathrm{CH}_{4}}$ and $\delta^{2} \mathrm{H}_{\mathrm{CH}_{4}}$ values from -110 to 
$-60 \%$ and -250 to $-100 \%$, respectively (Whiticar, 1999, Tazaz et al., 2013). In contrast, $\mathrm{CH}_{4}$ generated from acetate fermentation has a narrow range of $\delta^{13} \mathrm{C}_{\mathrm{CH}_{4}}$ and $\delta^{2} \mathrm{H}_{\mathrm{CH}_{4}}$ values encompassing values from -65 to $-48 \%$ and -370 to $-260 \%$, respectively (Whiticar, 1999).

The stable isotopic ratios of ${ }^{13} \mathrm{C}$ to ${ }^{12} \mathrm{C}$ and of ${ }^{2} \mathrm{H}$ to ${ }^{1} \mathrm{H}$ in $\mathrm{CH}_{4}$ are also known to reflect process, such as oxidation, that affect $\mathrm{CH}_{4}$ after it has formed. $\mathrm{CH}_{4}$ oxidation by $\cdot \mathrm{OH}$ causes the residual $\delta^{2} \mathrm{H}_{\mathrm{CH}_{4}}$ value to increase by $72 \%$ for every $1 \%$ increase in $\delta^{13} \mathrm{C}_{\mathrm{CH}_{4}}$ values (Saueressig et al., 2001). Methanotrophy, in contrast, imparts an increase in the $\delta^{2} \mathrm{H}_{\mathrm{CH}_{4}}$ value of $8.5 \%$ for every $1 \%$ increase in $\delta^{13} \mathrm{C}_{\mathrm{CH}_{4}}$ values (Feisthauer et al., 2011). These differences in the kinetic isotope fractionation factors associated with $\mathrm{CH}_{4}$ oxidation can help assess the oxidation process present in $\delta^{2} \mathrm{H}-\delta^{13} \mathrm{C}$ space. Thus, the $\delta^{13} \mathrm{C}_{\mathrm{CH}_{4}}$ and $\delta^{2} \mathrm{H}_{\mathrm{CH}_{4}}$ values may help determine the sources and sinks of $\mathrm{CH}_{4}$ in caves.

We studied the carbon and hydrogen stable isotopic compositions and mole fractions of $\mathrm{CH}_{4}$ and carbon dioxide $\left(\mathrm{CO}_{2}\right)$ in Buckner Cave, Southern Indiana to better characterize the $\mathrm{CH}_{4}$ dynamics of epigenic karst landscapes. We hypothesized that if $\mathrm{CH}_{4}$ in caves has an atmospheric source and cave processes decrease $\mathrm{CH}_{4}$ mole fractions in cave air, then $\mathrm{CH}_{4}$ should become more depleted as the distance from the cave entrance increases. We also asked, what are the biogeochemical processes that govern the mole fractions and stable isotopic composition of $\mathrm{CH}_{4}$ in karst cavities? Our work presents time-series data over 18 months and the first measurements of the ratio of deuterium to hydrogen $\left({ }^{2} \mathrm{H} /{ }^{1} \mathrm{H}\right)$ in $\mathrm{CH}_{4}$ from caves. Additionally we present a high resolution temporal study of a daily change in $\mathrm{CH}_{4}$ mole fractions in Buckner Cave. Our work shows that the stable isotopic composition of $\mathrm{CH}_{4}$ in 
Buckner Cave can be described by $\mathrm{CH}_{4}$ oxidation by methanotrophs as well as $\mathrm{CH}_{4}$ production from at least two different biogeochemical pathways.

\section{Geological Setting}

Buckner Cave is located within the Crawford Upland physiographic province of

Southern Indiana (Figure 1). The rock outcrops at the surface in the Crawford Upland consist of the interbedded sandstones and limestones of the Stephensport and West Baden groups (Conner, 1987; Lakey and Krothe, 1996). These rocks are resistant to erosion and cause an increase in topographic relief. Surface erosion by streams locally exposes the underlying limestones of the Blue River Group i.e. the Paoli Formation., the Saint Louis Formation, and the Saint Genevieve Formation. Buckner Cave is hosted in rocks of the Blue River Group, and is primarily hosted in the Saint Genevieve Fm., but the highest sections of the cave are located in the Paoli Limestone (Conner, 1987). The total vertical relief of Buckner Cave is $36.6 \mathrm{~m}$ with the lowest room having an elevation of $215.5 \mathrm{~m}$ a.s.l.(elevation at surface $259 \mathrm{~m}$ ) and the highest room having an elevation of $252.1 \mathrm{~m}$ a.s.1 (elevation at surface $255 \mathrm{~m}$ ).

Buckner Cave has been managed by the Richard Blenz Nature Conservancy since 2005. Buckner Cave is a wild cave and is visited by about 6 people per week. There is one natural entrance to Buckner Cave (Figure 2). A second entrance (Bull's Eye Pit) was blasted in 1992 to provide access for rescue purposes. This entrance has been closed, and is thought to be air tight. Air flow in Buckner Cave is also thought to be connected to the nearby Queen Blair Cave, which is lower in elevation than Buckner Cave, based on air tracer experiments (DesMarais, 
1971). Additionally, fractures in the limestone may allow for exchange with the atmosphere.

The average air temperature of Buckner Cave is $12.8^{\circ} \mathrm{C}$.

Buckner Cave is a branchwork cave with some anastomosing passages (Palmer, 1991). Some of the cave passages exhibit features indicative of formation by vadose processes while others appear to have formed by phreatic processes. Buckner Cave has two small drainages that eventually outflow at Big Blair Spring (DesMarais, 1981) (Figure 2).

\section{Methods}

\subsection{Air Sampling}

Air sampling was carried out in two discrete sampling campaigns. A preliminary study determined seasonal patterns of $\mathrm{CO}_{2}$ mole fractions in Buckner Cave by measuring monthly $\mathrm{CO}_{2}$ mole fractions at six locations from August 2010 through July 2012 to (Figure 2).

Sampling locations were selected based on their intersections with other passages, their distance from the main entrance, and their elevation. Distance to the main entrance was defined as the distance along the shortest passageway from a sampling location in Buckner Cave to the main entrance and was measured using the map of Buckner Cave shown in Figure 2. $\mathrm{CO}_{2}$ mole fractions were measured in-situ with a portable gas monitor (Gasman - Crowcon Detection Instruments Ltd., Erlanger, Kentucky, USA; range $0-50,000$ ppm; uncertainty, \pm 100 ppm). Daily high and low temperatures and total precipitation were measured at the Monroe County Airport approximately $5 \mathrm{~km}$ northwest of Buckner Cave (NCEI Asheville, NC). Data from this early part of the study indicate two distinct seasons of airflow for Buckner Cave (Figure 3). We defined summer airflow to encompass periods when $\mathrm{CO}_{2}$ mole fractions were above $2000 \mathrm{ppm}$. 
Data from this study also indicated that air exchange through the sealed Bull's Eye Pit entrance was not a major influence on airflow in Buckner Cave.

In the second, more detailed part of the study from July 2013 to March 2015, samples from sites 1 through 5 were collected monthly and analyzed for the mole fractions and isotopic compositions of $\mathrm{CH}_{4}$ and $\mathrm{CO}_{2}$ in Buckner Cave (Figure 2). Air sampling occurred during evenings from $6-8 \mathrm{pm}$. Air from sampling locations was collected in Tedlar ${ }^{\circledR}$ bags using 60 $\mathrm{mL}$ or $140 \mathrm{~mL}$ syringes via three way valves. Each $\operatorname{Tedlar}^{\circledR}$ bag was flushed three times with 60 or $140 \mathrm{~mL}$ of air and was emptied before collecting the final air sample of $\sim 550$ to $650 \mathrm{~mL}$. Samples were acquired in less than a minute.

An experiment to capture a daily change in the $\mathrm{CH}_{4}$ mole fraction of Buckner Cave air took place September 29, 2014. The high and low atmospheric temperatures on the 29th were 27.8 and $10.0^{\circ} \mathrm{C}$, respectively. Temperatures had been oscillating above and below the average cave temperature for 16 days prior to the experiment. At three times over 4 hours, $0.6 \mathrm{~L}$ of pure $\mathrm{CH}_{4}$ and $6 \mathrm{~mL}$ of pure sulfur hexafluoride $\left(\mathrm{SF}_{6}\right)$ were injected into the crawl way of Buckner Cave to check for differing behavior between the two gases (Figure 2). $60 \mathrm{~mL}$ of cave air was sampled roughly once every six minutes for five hours using pre-evacuated $50 \mathrm{~mL}$ serum vials. $\mathrm{CH}_{4}$ mole fraction data were recorded once every 72 seconds using an open-path tunable diode laser system (OPL) (GasFinder 2.0, Boreal Laser Inc., Spruce Grove, Alberta, Canada, wavelength $=1.653 \mu \mathrm{m}$ ) following the methods of Webster et al. (2015). The path between the laser and the retroreflector mirror was $30 \mathrm{~m}$.

\subsection{Chemical and Isotopic Analyses}


A Varian 450 gas chromatograph (GC) (Varian - Agilent Technologies, Palo Alto, California) was used to measure $\mathrm{CH}_{4}, \mathrm{CO}_{2}$, and $\mathrm{SF}_{6}$ mole fractions. The chromatograph was fitted with a flame ionization detector (FID) for $\mathrm{CH}_{4}$, a thermal conductivity detector (TCD) for $\mathrm{CO}_{2}$, and an electron capture detector (ECD) for $\mathrm{SF}_{6} \cdot \mathrm{CH}_{4}$ mole fraction standards of 10 and $100 \mathrm{ppm}$ in a balance of $\mathrm{N}_{2}$ from Air Liquide America Specialty Gasses LLC (Plumsteadville, Pennsylvania), and dilutions of the $10 \mathrm{ppm}$ standard to $2 \mathrm{ppm}$, and a pure He blank were used to determine sample $\mathrm{CH}_{4}$ mole fractions. The FID exhibited an analytical repeatability better than $5 \%$. A \pm 0.10 ppm uncertainty was assigned to $\mathrm{CH}_{4}$ mole fraction measurements based on replicates of low mole fraction samples, i.e. $<2.0 \mathrm{ppm} . \mathrm{CO}_{2}$ standards of 100, 1000, and 10,000 ppm in balances of $\mathrm{N}_{2}$ (Air Liquide), and a pure He blank were used to determine sample $\mathrm{CO}_{2}$ mole fractions. $\mathrm{CO}_{2}$ samples were assigned an uncertainty of $\pm 5 \%$ based on the analytical repeatability of the $\mathrm{CO}_{2}$ standards. $\mathrm{CO}_{2}$ mole fraction data were also measured using a GasBench II inlet connected to a Delta Plus XP isotope-ratio mass-spectrometer (IRMS). Samples measured for mole fraction on the IRMS were given errors of $50 \mathrm{ppm}$ for samples below $600 \mathrm{ppm}$ (95\% confidence intervals) and were given errors of $5 \%$ for samples above $600 \mathrm{ppm} . \mathrm{SF}_{6}$ mole fractions were calculated with in-house standards created from pure $\mathrm{SF}_{6}$ by adding known volumes of pure $\mathrm{SF}_{6}$ to a balance of Air Zero (Air Liquide, purified air, with $\mathrm{CO}_{2}, \mathrm{H}_{2} \mathrm{O}$, and hydrocarbons removed). $\mathrm{SF}_{6}$ standards ranged from 0 to $700 \mathrm{ppb}$, and the repeatability of the standards were $\pm 1 \%$.

The carbon stable isotopic compositions of $\mathrm{CH}_{4}$ and $\mathrm{CO}_{2}$ were measured with an IRMS and are reported as conventional $\delta^{13} \mathrm{C}_{\mathrm{CH}_{4}}$ and $\delta^{13} \mathrm{C}_{\mathrm{CO}_{2}}$ values in \%o along the carbon isotopic scale anchored to Vienna Pee Dee Belemnite (VPDB). $\mathrm{CH}_{4}$ samples were measured in continuous-flow mode using $\mathrm{CH}_{4}$ preconcentration and cryofocusing (Miller et al., 2002) and a 
gas chromatography-oxidation/pyrolysis-IRMS (GC-ox/pyr-IRMS) interface as briefly described by Cadieux et al., (2016). A variable sample extraction time was used to isolate approximately $0.4 \mu \mathrm{mol}$ of $\mathrm{CH}_{4}$ from each sample prior to introduction to the GC-ox/pyr-IRMS. $\mathrm{CH}_{4}$ standards with $\delta^{13} \mathrm{C}$ values of $-38.25 \pm 0.03,+19.89 \pm 0.05,-39.40 \pm 0.01$, and $-57.75 \pm$ $0.03 \%$ (Methane \#1, \#3, \#6, and ALM, http://pages.iu.edu/ aschimme/welcome.html) were used for 2-point calibrations to normalize measured ${ }^{13} \mathrm{C} /{ }^{12} \mathrm{C}$ ratios to the VPDB scale. Ratios of ${ }^{13} \mathrm{C} /{ }^{12} \mathrm{C}$ in $\mathrm{CO}_{2}$ from cave air were measured in continuous-flow mode using a GasBench II inlet (Tu et al., 2001). Measured ${ }^{13} \mathrm{C} /{ }^{12} \mathrm{C}$ ratios of $\mathrm{CO}_{2}$ from cave air were converted to the VPDB scale using a single isotopically characterized in-house standard that has a value of $12.0 \pm 0.2$ $\%$.

The hydrogen stable isotopic compositions of $\mathrm{CH}_{4}$ are reported along the Vienna Standard Mean Ocean Water-Standard Light Antarctic Precipitation (VSMOW-SLAP) isotopic scale. Samples are reported in \%o as $\delta^{2} \mathrm{H}_{\mathrm{CH}_{4}}$ values. $\delta^{2} \mathrm{H}_{\mathrm{CH}_{4}}$ values were measured with an IRMS in continuous-flow mode using $\mathrm{CH}_{4}$ preconcentration and cryofocusing (Miller et al., 2002) and a GC-ox/pyr-IRMS interface. $\mathrm{CH}_{4}$ standards with $\delta^{2} \mathrm{H}_{\mathrm{CH}_{4}}$ values of $-161 \pm 2,+2.2 \pm 1.2,-153 \pm$ 2, and $-273 \pm 3 \%$ (Methane \#1, \#3, \#6, and ALM, http://pages.iu.edu/ aschimme/welcome.html) were used for 2-point calibration along the VSMOW-SLAP scale. A variable sample extraction time was used to isolate roughly $0.8 \mu \mathrm{mol}$ of $\mathrm{CH}_{4}$ from each sample prior to introduction to the GC-ox/pyr-IRMS.

Errors associated with $\delta^{13} \mathrm{C}_{\mathrm{CH}_{4}}$ and $\delta^{2} \mathrm{H}_{\mathrm{CH}_{4}}$ values were calculated using a standard curve that accounted for the peak size of the measurement. Larger errors are associated with small 
peak sizes. Analytical repeatability of internal standards ranged from 0.13 to $0.4 \%$ for $\delta^{13} \mathrm{C}_{\mathrm{CH}_{4}}$ and from to 3 to $20 \%$ in $\delta^{2} \mathrm{H}_{\mathrm{CH}_{4}}$.

\subsection{Quantitative analyses}

Samples and data were screened for quality control. If a sample bag had been shown to exhibit a leak for one analyte, analyses of other analytes concurrent or after that point in time from that bag were discarded. Supplemental materials 1 and 2 show all of the collected data. All samples are reported with $95 \%$ confidence intervals.

Several different modeling techniques were used to assess the processes affecting trace gas geochemistry in Buckner Cave. Linear regression models were used to determine the effect of distance and elevation on $\mathrm{CH}_{4}$ and $\mathrm{CO}_{2}$ mole fractions in Buckner Cave. The sources of $\mathrm{CO}_{2}$ entering Buckner Cave were assessed using forward modeling techniques assuming mixing between an atmospheric endmember and endmembers of varying isotopic signatures following the methods of Spötl et al. (2005). Due to noise in samples below $650 \mathrm{ppm} \mathrm{CO}_{2}$, source signatures were only calculated for samples with $\mathrm{CO}_{2}$ mole fractions greater than or equal to $650 \mathrm{ppm}$.

Rayleigh distillation models were used as the theoretical basis to examine changes in the stable isotopic composition of atmospheric $\mathrm{CH}_{4}$ caused by methanotrophy or $\cdot \mathrm{OH}$ oxidation. The $\delta$ value of an isotope system in a molecule of interest in cave air can be modeled as

$$
\delta_{c}=\left(\delta_{i}+1000\right) f^{(-\alpha+1)}-1000
$$


where $\delta_{c}$ is the current $\delta$-value of a particular isotope system in cave air after partial consumption, $\delta_{i}$ is the initial $\delta$-value of the isotope system in cave air, $f$ is the fraction of the molecule of remaining, and $\alpha$ the kinetic isotope fractionation factor (Barker and Fritz, 1981; Feisthauer et al., 2011). $\alpha$ values of 1.018 and 1.2413 were used to model bacterial methanotrophy (Coleman et al., 1981; Feisthauer et al., 2011), and $\alpha$ values of 1.0039 and 1.294 were used to model changes in $\delta^{13} \mathrm{C}_{\mathrm{CH}_{4}}$ and $\delta^{2} \mathrm{H}_{\mathrm{CH}_{4}}$ values caused by $\cdot \mathrm{OH}$ oxidation (Saueressig et al., 2001).

\section{Results}

The mole fractions and stable isotopic compositions of $\mathrm{CH}_{4}$ and $\mathrm{CO}_{2}$ in Buckner Cave varied both spatially and seasonally, following a pattern of thermally-driven circulation in winter and stagnation in summer (Figure 4). $\mathrm{CH}_{4}$ mole fractions were highest in Buckner Cave during winter and lowest in Buckner Cave during summer whereas $\mathrm{CO}_{2}$ mole fractions were lowest in winter and highest in summer (Figure 4B). $\mathrm{CH}_{4}$ mole fractions in Buckner Cave ranged from $<0.1$ to $1.9 \pm 0.1 \mathrm{ppm}$, and $\mathrm{CO}_{2}$ mole fractions ranged from $330 \pm 50$ to $5300 \pm$ $500 \mathrm{ppm}$. The outside atmosphere showed little variation in $\mathrm{CH}_{4}$ and $\mathrm{CO}_{2}$ mole fractions with $\mathrm{CH}_{4}$ ranging from $1.86 \pm 0.13$ to $2.17 \pm 0.10 \mathrm{ppm}$ and $\mathrm{CO}_{2}$ ranging from $400 \pm 20$ to $520 \pm 30$ ppm. $\delta^{13} \mathrm{C}_{\mathrm{CH}_{4}}, \delta^{2} \mathrm{H}_{\mathrm{CH}_{4}}$, and $\delta^{13} \mathrm{C}_{\mathrm{CO}_{2}}$ values of the external atmosphere also exhibited narrow ranges with $\delta^{13} \mathrm{C}_{\mathrm{CH}_{4}}$ values ranging from $-49 \pm 3 \%$ to $-42.7 \pm 0.4, \delta^{2} \mathrm{H}_{\mathrm{CH}_{4}}$ values ranging from $-110 \pm 30 \%$ to $-80 \pm 30 \%$, and $\delta^{13} \mathrm{C}_{\mathrm{CO}_{2}}$ values ranging from $-10.5 \pm 0.5 \%$ to $-9.2 \pm 0.4 \%$. Winter cave air was compositionally more similar to the outside atmosphere than summer cave air and had higher $\mathrm{CH}_{4}$ mole fractions than summer air (Independent 2-group Mann-Whitney $\mathrm{U}$ 
Test, $W=254.5, p=0.0006) . \delta^{13} \mathrm{C}_{\mathrm{CH}_{4}}$ and $\delta^{2} \mathrm{H}_{\mathrm{CH}_{4}}$ values of cave air were more variable during summer than during winter and were more similar to the respective values of outside atmospheric $\mathrm{CH}_{4}$ during winter than during summer (Figure $4 \mathrm{E}, \mathrm{F}$ ). $\delta^{13} \mathrm{C}_{\mathrm{CO}_{2}}$ values were more similar to the respective values of the outside atmosphere during winter than during summer (Figure 4D). Winter $\delta^{13} \mathrm{C}_{\mathrm{CO}_{2}}$ values ranged from-20.1 \pm 0.2 to $-13.8 \pm 0.4 \%$, while, with the exception of Site 1 , summer values were close to $-23 \%$, ranging from $-23.68 \pm 0.11$ to -20.96 $\pm 0.16 \%$.

The $\mathrm{CH}_{4}$ mole fraction in Buckner Cave was observed to be capable of daily fluctuations (Figure 5). $\mathrm{CH}_{4}$ mole fractions were relatively high in the crawl way near the entrance at the start of the experiment. The wind direction was also felt blowing into the cave at the beginning of the experiment and blowing out of the cave at the end of the experiment (Webster and Mirza, field observations). Over the course of the experiment baseline $\mathrm{CH}_{4}$ mole fractions decreased from $1.53 \pm 0.03$ to $0.339 \pm 0.017 \mathrm{ppm} . \mathrm{CH}_{4}$ and $\mathrm{SF}_{6}$ showed the same behavior when injected into Buckner Cave. Increases in $\mathrm{CH}_{4}$ mole fractions were registered before increases in $\mathrm{SF}_{6}$ mole fractions, but $\mathrm{SF}_{6}$ was measured as $\mathrm{CH}_{4}$ mole fractions exhibited minor stability before falling back to or below $\mathrm{CH}_{4}$ mole fractions prior to the injection of the gases.

Atmospheric $\mathrm{CH}_{4}$ mole fractions in Buckner Cave were also related to the distance, $d$ (m), from the Main Entrance (Figure 6). Rooms farther from the Main Entrance showed lower $\mathrm{CH}_{4}$ mole fractions during both summer and winter based on a correlation analysis $\left(\left[\mathrm{CH}_{4}\right]_{\text {summer }}\right.$ $=-0.0025 \pm 0.0008 d+1.4 \pm 0.3, r^{2}=0.59 ; p=8 * 10^{-7} ;\left[\mathrm{CH}_{4}\right]_{\text {winter }}=-0.0024 \pm 0.0006 d+1.9$ $\left.\pm 0.2, r^{2}=0.62, p=4 * 10^{-8}\right) . \mathrm{CH}_{4}$ and $\mathrm{CO}_{2}$ mole fractions were not related to the elevation of sites in Buckner Cave $\left(\mathrm{CH}_{4}\right]_{\text {summer }}, r^{2}=0.0, p=0.9 ;\left[\mathrm{CH}_{4}\right]_{\text {winter }}, r^{2}=0.09, p=0.09$; 
$\left.\left[\mathrm{CO}_{2}\right]_{\text {summer }}, r^{2}=0.17, p=0.30 ;\left[\mathrm{CO}_{2}\right]_{\text {winter }}, r^{2}=0.20, p=0.23\right)$. The $\mathrm{CH}_{4}$ mole fraction in Buckner Cave was related to the $\mathrm{CO}_{2}$ mole fraction by an inverse power function $\left(\left[\mathrm{CH}_{4}\right]=\right.$ $\left.354.5\left[\mathrm{CO}_{2}\right]^{-0.92}, r^{2}=0.63\right)$.

Following the approach of Spötl et al., (2005) we inferred $\mathrm{CO}_{2}$ sources with $\delta^{13} \mathrm{C}_{\mathrm{CO}_{2}}$ values ranging from $-35 \pm 2$ to $-20[-1,+0.8] \%$ are entering Buckner Cave (Figure 7). Winter sources of $\mathrm{CO}_{2}$ have $\delta^{13} \mathrm{C}$ values that range from $-35 \pm 2$ to $-24 \pm 2 \%$, with an average value of $-28.7 \pm 0.4 \%$. The sources of $\mathrm{CO}_{2}$ entering Buckner Cave during summer airflow appear to range from $-26.7 \pm 0.5$ to $-20[-1,+0.8] \%$ with an average value of $-24.08 \pm 0.08 \%$. Samples from winter show the input of more negative $\delta^{13} \mathrm{C}_{\mathrm{CO}_{2}}$ than summer samples (two sample $t$-test unequal variance, $t_{18}$ stat $\left.=-3.33, p=0.0019\right)$.

Cave air $\delta^{13} \mathrm{C}_{\mathrm{CH}_{4}}$ and $\delta^{2} \mathrm{H}_{\mathrm{CH}_{4}}$ values ranged from -58.7 to $+7 \%$ and from -170 to $+10 \%$ o respectively (Figure 4). Several points exhibit more negative $\delta^{13} \mathrm{C}_{\mathrm{CH}_{4}}$ and $\delta^{2} \mathrm{H}_{\mathrm{CH}_{4}}$ values than would be expected if the oxidation of atmospheric $\mathrm{CH}_{4}$ by methanotrophy or $\cdot \mathrm{OH}$ oxidation were the only process acting on $\mathrm{CH}_{4}$ in Buckner Cave (Figures 8, 9). A plot of the data in $\delta^{2} \mathrm{H}_{\mathrm{CH}_{4}}$ vs. $\delta^{13} \mathrm{C}_{\mathrm{CH}_{4}}$ space shows that a cluster of points plots near the values for atmospheric $\mathrm{CH}_{4}$ (Figure 10). Other points, i.e. points that plot to the left of the atmosphere and below the atmosphere, suggest that non-atmospheric $\mathrm{CH}_{4}$ sources are entering Buckner Cave (Figure 10).

\section{Discussion}

\subsection{Air Flow and Trace Gas Mole Fractions in Buckner Cave}


The patterns in $\mathrm{CH}_{4}$ mole fractions in Buckner Cave suggest that $\mathrm{CH}_{4}$ is being removed from cave air, and that Buckner Cave is dynamically ventilated. Observations of daily and seasonal changes in $\mathrm{CH}_{4}$ and $\mathrm{CO}_{2}$ mole fractions in Buckner Cave suggest that external air enters Buckner Cave through the main entrance when outside temperatures are cooler than cave air temperatures (Figures 3,4). Additionally, $\mathrm{CH}_{4}$ mole fractions were close to atmospheric mole fractions as air flowed into the cave on Sep. $29^{\text {th }}$, but $\mathrm{CH}_{4}$ mole fractions decreased as air flow in the cave reversed (Figure 5). Seasonality in Buckner Cave resulted in mole fractions of $\mathrm{CH}_{4}$ and $\mathrm{CO}_{2}$ that were more similar to the atmosphere in the winter than in the summer (Figure 4). Seasonality has been observed in other caves and results in high $\mathrm{CO}_{2}$ mole fractions during times of low atmospheric influence, whereas low $\mathrm{CO}_{2}$ mole fractions relate to times of high atmospheric influence (Mattey et al., 2010; Kowalczk and Froelich, 2010; Gregorič et al., 2011; Gregorič et al., 2013; Baldini et al., 2008).

The mole fraction of $\mathrm{CH}_{4}$ in the air of Buckner Cave is related to the amount of atmospheric influence in Buckner Cave. $\mathrm{CH}_{4}$ mole fractions were more similar to atmospheric values during winter airflow when cave air $\mathrm{CO}_{2}$ also exhibited mole fractions and stable isotopic compositions that were more similar to atmospheric values (Figure 4). $\mathrm{CH}_{4}$ and $\mathrm{CO}_{2}$ mole fractions in Buckner Cave are generally inversely correlated, although smaller scale deviations from this pattern are observed (Figure 4). The small scale deviations from the pattern occur in May when both $\mathrm{CH}_{4}$ and $\mathrm{CO}_{2}$ mole fractions are relatively low, and in October when both $\mathrm{CH}_{4}$ and $\mathrm{CO}_{2}$ mole fractions are relatively high, and may be due to changing flow regimes in the cave. The trend of inversely correlated $\mathrm{CH}_{4}$ and $\mathrm{CO}_{2}$ mole fractions in Buckner cave matches observations of cave air from caves in Gibraltar, Spain, and Australia (Mattey et al., 2013; Fernandez-Cortes et al., 2015; McDonough et al., 2016). 
The $\delta^{13} \mathrm{C}_{\mathrm{CO}_{2}}$ values of air in Buckner Cave also suggest that cave air flow was faster in winter than in summer. Winter $\mathrm{CO}_{2}$ sources are estimated to have an average $\delta^{13} \mathrm{C}_{\mathrm{CO}_{2}}$ value of $-28.7 \pm 0.4 \%$ which is more negative than the estimated average $\delta^{13} \mathrm{C}_{\mathrm{CO}_{2}}$ value of summer sources, $-24.08 \pm 0.08 \%$. The ultimate source of this ${ }^{13} \mathrm{C}$-depleted $\mathrm{CO}_{2}$ entering Buckner Cave in winter is likely soil $\mathrm{CO}_{2}$ which has $\delta^{13} \mathrm{C}_{\mathrm{CO}_{2}}$ values near $-24 \%$ (Amundson et al., 1998; Breecker et al., 2012). However, the diffusivity of light isotopologues through porous materials can be preferentially enhanced through pressure pumping, which occurs in porous materials as air flows past them (Bowling and Massman, 2011). As air flows through Buckner Cave in the winter, pressure pumping in the karst and epikarst may draw more ${ }^{13} \mathrm{C}$-depleted $\mathrm{CO}_{2}$ into cave air. Source $\delta^{13} \mathrm{C}_{\mathrm{CO}_{2}}$ values as low as $-32 \%$ have been observed in snowpack and other caves during times of greater atmospheric influence when the source has been considered to derive from soil $\mathrm{CO}_{2}$ (Bowling and Massman, 2011; Garcia-Anton et al., 2014). Slower airflow in summer is suggested by increased $\mathrm{CO}_{2}$ mole fractions and stable isotopic compositions of $\mathrm{CO}_{2}$ with $\delta^{13} \mathrm{C}_{\mathrm{CO}_{2}}$ values that correspond to values observed for $\mathrm{CO}_{2}$ in the soils and epikarst, i.e. near -24 \%o (Cernusak et al., 2009; Mattey et al., 2010; Kowalczk and Froelich, 2010; Breecker et al., 2012; Peyraube et al., 2013; Garcia-Anton et al., 2014; Fernandez-Cortes et al., 2015).

Secondary ventilation driven by changes in external wind speed and wind direction is likely present in Buckner Cave (Kowalczk and Froelich, 2010; Breitenbach et al., 2015). Cave air close to the main entrance may be prone to enhanced exchange by wind-forced mixing, and may explain higher $\mathrm{CH}_{4}$ mole fractions at Site 1 (the entry room) during summer when the interior of Buckner Cave is relatively less ventilated. The summer relationship between $\mathrm{CH}_{4}$ mole fractions and distance from the cave entrance may follow an inverse power function 
(Figure 6). This relationship may suggest that two fluids with distinct composition are physically close but experience a barrier to mixing. If this is applicable to Buckner Cave, it may suggest that airflow in the entry room is fundamentally different from flow in the rest of the cave during summer.

\section{2 $\mathrm{CH}_{4}$ Dynamics of Buckner Cave}

The $\mathrm{CH}_{4}$ mole fractions, $\delta^{13} \mathrm{C}_{\mathrm{CH}_{4}}$ values, and $\delta^{2} \mathrm{H}_{\mathrm{CH}_{4}}$ values offer additional insight into the sources and sinks of $\mathrm{CH}_{4}$ in Buckner Cave (Figures 8, 9, 10). While the general pattern of increasing $\delta^{13} \mathrm{C}_{\mathrm{CH}_{4}}$ and $\delta^{2} \mathrm{H}_{\mathrm{CH}_{4}}$ values as $\mathrm{CH}_{4}$ mole fraction decreases indicates that $\mathrm{CH}_{4}$ oxidation is taking place in Buckner Cave, data that plot below and to the left of the theoretical oxidation trends show that non-atmospheric sources of $\mathrm{CH}_{4}$ with low $\delta^{13} \mathrm{C}_{\mathrm{CH}_{4}}$ and $\delta^{2} \mathrm{H}_{\mathrm{CH}_{4}}$ values are entering parts of the cave (Figures 8,9). When $\delta^{13} \mathrm{C}_{\mathrm{CH}_{4}}$ and $\delta^{2} \mathrm{H}_{\mathrm{CH}_{4}}$ values are plotted against each other, $\mathrm{CH}_{4}$ generated from other biogeochemical pathways appears to be entering the cave (Figure 10).

$\mathrm{CH}_{4}$ produced from carbonate reduction appears to be entering Buckner Cave. Several samples from Buckner Cave plot near known $\mathrm{CH}_{4}$ produced from carbonate reduction (Figure 10). Oxidation of this $\mathrm{CH}_{4}$ source in Buckner Cave appears to result in a positive shift in the $\delta^{13} \mathrm{C}_{\mathrm{CH}_{4}}$ and $\delta^{2} \mathrm{H}_{\mathrm{CH}_{4}}$ values that could be caused by methanotrophy or $\cdot \mathrm{OH}$ oxidation. $\mathrm{CO}_{2}$ reduction has been observed in the anoxic interior of biological soil crusts in desert soils (Angel et al., 2011), and it is possible that $\mathrm{CO}_{2}$ reduction occurs in locally anoxic soil microenvironments above karst, or locally anoxic epikarst environments. This $\mathrm{CH}_{4}$ appears to 
be partially oxidized resulting in slightly more positive values (i.e. $\delta^{13} \mathrm{C}_{\mathrm{CH}_{4}}$ value nears $-62 \%$ and $\delta^{2} \mathrm{H}_{\mathrm{CH}_{4}}$ values near $-100 \%$ ) than are typically observed from carbonate reduction.

A cluster of points plots below and to the top right of an atmospheric $\mathrm{CH}_{4}$ source. Five samples in this cluster plot within the region of thermogenic $\mathrm{CH}_{4}$, i.e. $\mathrm{CH}_{4}$ from deep geologic sources, such as shale gas (Figure 10) (Whiticar, 1999; Etiope and Sherwood Lollar, 2013). Thermogenic $\mathrm{CH}_{4}$ could be a minor source of $\mathrm{CH}_{4}$ in Buckner Cave. However the migration of geological $\mathrm{CH}_{4}$ into Bucker Cave would likely occur through a geologic fault injecting $\mathrm{CH}_{4}$ at a point source. During periods of slower air flow, specifically during summer, seepage from a geological source would likely create an elevated, quasi-constant $\mathrm{CH}_{4}$ mole fraction in a specific part of the cave near the seep as long as the rate of influx and airflow patterns are relatively constant. The $\mathrm{CH}_{4}$ in this room of the cave would also have a temporally similar isotopic composition due to the stable seepage source. Such a pattern was not observed which suggests that other $\mathrm{CH}_{4}$ sources are likely contributing to the mole fractions of $\mathrm{CH}_{4}, \delta^{13} \mathrm{C}_{\mathrm{CH}_{4}}$, and $\delta^{2} \mathrm{H}_{\mathrm{CH}_{4}}$ values observed in Buckner Cave.

Since the migration of thermogenic $\mathrm{CH}_{4}$ in Buckner Cave is unlikely, the data suggest that $\mathrm{CH}_{4}$ generated by acetate fermentation is entering Buckner Cave. Acetoclastic methanogenesis may occur in the soil above the cave, the epikarst, or in the cave itself. The samples from Buckner Cave plot along a methanotrophic oxidation trend (Figure 10). Only one observation plots off of this trend. Oxidation of acetoclastically produced $\mathrm{CH}_{4}$ may occur in-situ or prior to entering the cave. At Site 2, a slightly increased $\mathrm{CH}_{4}$ mole fraction in June 2014 is compatible with the oxidation of $\mathrm{CH}_{4}$ that had been produced by acetoclastic methanogenesis (Figures 4,10 ). Additionally, the $\mathrm{CH}_{4}$ mole fraction, $\delta^{13} \mathrm{C}_{\mathrm{CH}_{4}}$, and $\delta^{2} \mathrm{H}_{\mathrm{CH}_{4}}$ values associated with 
these points can be modeled assuming that a localized pulsed $\mathrm{CH}_{4}$ source enters the cave, raises the $\mathrm{CH}_{4}$ mole fraction to about $0.5 \mathrm{ppm}$, and is subsequently oxidized by methanotrophy.

It has recently been suggested that ions and radicals associated with radon decay may be oxidizing $\mathrm{CH}_{4}$ in caves (Fernandez-Cortes et al., 2015). Many isotopic compositions of $\mathrm{CH}_{4}$ in Buckner Cave cannot be accounted for if it is assumed that (i) $\mathrm{CH}_{4}$ enters Buckner Cave from the atmosphere, through carbonate reduction, and through acetate fermentation and (ii) that $\mathrm{CH}_{4}$ is removed from the cave atmosphere through reactions involving the $\cdot \mathrm{OH}$ radical. Conversely, if it is assumed that (i) $\mathrm{CH}_{4}$ sources in Buckner Cave include the atmosphere, carbonate reduction, and acetate fermentation and (ii) that $\mathrm{CH}_{4}$ is removed from the cave atmosphere by methanotrophy, only one point plost outside of the plausibility envelope of the model (Figure 10). However, if a thermogenic source is also assumed to be entering Buckner Cave and the - $\mathrm{OH}$ radical is a possible mechanism for $\mathrm{CH}_{4}$ removal in Buckner Cave, then three points plot outside of the plausibility ranges of the model.

\subsection{Future Directions}

Quantitative measurements of the oxidative removal of atmospheric $\mathrm{CH}_{4}$ in subterranean karst environments are needed for future incorporation of $\mathrm{CH}_{4}$ consumption by karst into global models of greenhouse gas sources and sinks. For example, $\mathrm{CH}_{4}$ fluxes in caves could be calculated via combined measurements of $\mathrm{CH}_{4}$ mole fraction in caves and simultaneous wind speed measurements. Eddy covariance above karst landscapes may be a suitable method to determine the amount of atmospheric $\mathrm{CH}_{4}$ being consumed by karst because this method is an effective means of measuring $\mathrm{CH}_{4}$ flux in arctic landscapes (Sachs et al., 2008; Tagesson et al., 
2012). A third appropriate method may be quantification of $\mathrm{CH}_{4}$ oxidation in karst by in-situ chamber flux experiments, followed by global extrapolation across all karst landscapes. Caveats would be represented by (i) uncertain estimates of the total subterranean pore space that is able to exchange air with the global atmosphere, and (ii) likely contrasting methanotrophic kinetics across different climates and altitudes. The simultaneous utilization of multiple approaches will yield valuable insight on subterranean $\mathrm{CH}_{4}$ consumption in all large subterranean cavities and fractures at varying spatial and climatic scales.

\section{Summary and Conclusions}

Buckner Cave is a net $\mathrm{CH}_{4}$ sink because cave air is exchanging with the atmosphere and the $\mathrm{CH}_{4}$ mole fractions in cave air were generally below those of the outside atmosphere. Mounting evidence points to subterranean cave environments serving as a global sink for atmospheric $\mathrm{CH}_{4}$. Different air flow regimes in Buckner Cave throughout the year resulted in distinct seasonal variations of $\mathrm{CH}_{4}$ and $\mathrm{CO}_{2}$ mole fractions. The pattern of stable isotopic compositions of $\mathrm{CH}_{4}$ in Buckner Cave can be best explained by an atmospheric $\mathrm{CH}_{4}$ source, oxidation of $\mathrm{CH}_{4}$ by methanotrophic bacteria, and at least two isotopically different nonatmospheric sources of $\mathrm{CH}_{4}$ (Figure 10). Our observations of non-atmospheric $\mathrm{CH}_{4}$ sources entering the air of Buckner Cave agree with observations from St. Michael's Cave in Gibraltar

where the $\delta^{13} \mathrm{C}_{\mathrm{CH}_{4}}$ values of cave air suggested methanogenesis occurred within the karst system (Mattey et al., 2013). Our data also agree with observations from Garden and Wellington caves in Australia where methanotrophy was determined to be the reason for the sub-atmospheric $\mathrm{CH}_{4}$ 
mole fractions in those caves (McDonough et al., 2016). Further studies are needed to quantitatively constrain the oxidative loss of $\mathrm{CH}_{4}$ in subterranean karst environments.

\section{Acknowledgements}

This material is based upon work supported by the U.S. Department of Energy, Office of Science, Office of Basic Energy Sciences, Chemical Sciences, Geosciences, and Biosciences Division under Award Number DE-SC0006978. This study was partially funded by: NASA, Astrobiology Science and Technology for Exploring Planets (Award \# NNX11AJ01G); a National Speleological Society research award; the Cleveland Grotto; the Bloomington Indiana Grotto; the Central Indiana Grotto; and the Richard Blenz Nature Conservancy. Several discussions with G. Etiope, J.T. Lennon, K.J. Locey, and P.L. Griffin provided insight into the data. T.V. Royer made analytical gas chromatography available. We are indebted to three anonymous reviewers for their constructive feedback.

\section{References}

Adushkin, V.V., Kudryavtsev, V.P., 2010. Global methane flux into the atmosphere and its seasonal variations. Izvestiya, Phyicss of the Solid Earth 46(4), 350-357. http://dx.doi.org/10.1134/S1069351310040075

Angel, R., Matthies D., Conrad, R., 2011. Activation of methanogenesis in arid biological soil crusts despite the presence of oxygen. PLoS ONE 6(5), e20453.

http://dx.doi.org/10.1371/journal.pone.0020453 
Amundson, R., Stern L., Baisden T., Wang, Y., 1998. The isotopic composition of soil and soilrespired $\mathrm{CO}_{2}$. Geoderma 82, 83-114. http://dx.doi.org/10.1016/S0016-7061(97)00098-0

Atkinson, T.C., Smart, P.L., Wigley, T.M.L., 1983. Climate and natural radon levels in Castleguard Cave, Columbia Icefields, Alberta, Canada. Arctic and Alpine Research 15(4), 487-502. http://dx.doi.org/10.2307/1551235

Baldini, J.U.L., McDermott, F., Hoffman, D.L., Richards, D.A., Clipson, N., 2008. Very highfrequency and seasonal cave atmosphere $P_{\mathrm{CO}_{2}}$ variability: Implications for stalagmite growth and oxygen isotope-based paleoclimate records. Earth and Planetary Science Letters 272, 118-129. http://dx.doi.org/10.1016/j.eps1.2008.04.031

Barker, J.F., Fritz, P., 1981. Carbon isotope fractionation during microbial methane oxidation. Nature 293, 289-291. http://dx.doi.org/10.1038/293289a0

Bowling, D.R., Massman, W.J., 2011. Persistent wind-induced enhancement of $\mathrm{CO}_{2}$ transport in a mountain forest snowpack. Journal of Geophysical Research 116(G4006). http://dx.doi.org/10.1029/2011JG001722

Breecker, D.O., Payne, A.E., Quade, J., Banner, J.L., Ball, C.E., Meyer, K.W., Cowan, B.D., 2012. The sources and sinks of $\mathrm{CO}_{2}$ in caves under mixed woodland and grassland vegetation. Geochimica et Cosmochimica Acta 96, 230-246. http://dx.doi.org/10.1016/j.gca.2012.08.023

Breitenbach, S.F.M., Lechleitner, F.A., Meyer, H., Diengdoh, G., Mattey, D., Marwan, N., 2015. Cave ventilation and rainfall signals in dripwater in a monsoonal setting - a monitoring study from NE India. Chemical Geology 402, 111-124. http://dx.doi.org/10.1016/j.chemgeo.2015.03.011 
Cadieux, S.B., White, J.R., Sauer, P.E., Peng, Y., Goldman, A.E., Pratt, L.M., 2016. Large fractionations of $\mathrm{C}$ and $\mathrm{H}$ isotopes related to methane oxidation in Arctic lakes. Geochimica et Cosmochimica Acta 187, 141-155. http://dx.doi.org/10.1016/j.gca.2016.05.004

Cernusak, L.A., Tcherkez, G., Keitel, C., Cornwell, W.K., Santiago, L.S., Knohl, A., Barbour, M.M., Williams, D.G., Reich, P.B., Ellsworth, D.S., Dawson, T.E., Griffiths, H.G., Farquhar, G.D., Wright, I.J., 2009. Why are non-photosynthetic tissues generally ${ }^{13} \mathrm{C}$ enriched compared with leaves in $\mathrm{C}_{3}$ plants? Review and synthesis of current hypotheses. Functional Plant Biology 36, 199-213. http://dx.doi.org/10.1071/FP08216

Ciais, P., Sabine, C., Bala, G., Bopp, L., Brovkin, V., Canadell, J., Chhabra, A., DeFries, R., Galloway, J., Heimann, M., Jones, C., Le Quéré, C., Myneni, R.B., Piao, S., Thornton, P., 2013. Carbon and other biogeochemical cycles. In Climate Change 2013: The Physical Science Basis. Contribution to Working Group I to the the Fifth Assessment Report of the Intergovernmental Panel on Climate Change (Stocker, T.F., Qin, D., Plattner, G.-K., Tignor, M., Allen, S.K., Boschung, A., Nauels, A., Xia, Y., Bex, V., Midgley, P.M. eds.). Cambridge University Press, Cambridge, United Kingdom and New York, NY, USA. https://www.ipcc.ch/pdf/assessmentreport/ar5/wg1/WG1AR5_Chapter06_FINAL.pdf

Coleman D.D., Risatti J.B., Schoell M., 1981. Fractionation of carbon and hydrogen isotopes by methane-oxidizing bacteria. Geochimica et Cosmochimica Acta 45(7), 1033-1037. http://dx.doi.org/10.1016/0016-7037(81)90129-0 
Conner, G.A., 1987. Stratigraphic sections in the Ste. Genevieve Formation (Middle Mississippian) exposed in Garrison Chapel karst area caverns - Western Monroe County, Indiana USA. International Journal of Speleology 16, 79-94. http://dx.doi.org/10.5038/1827-806X.16.3.2

Craig, H., Chou, C.C., 1982. Methane: The record in the polar ice cores. Geophysical Research Letters 9(11), 1221-1224. http://dx.doi.org/10.1029/GL009i011p01221

Curl, R.L., 1966. Caves as a measure of karst. The Journal of Geology 74, 798-830. http://www.jstor.org/stable/30060120

DesMarais, D.J., 1971. Queen Blair. The Bloomington Indiana Grotto Newsletter 10(2), 27-28.

DesMarais, D.J., 1981. Subterranean stream piracy in the Garrison Chapel Karst Valley, Indiana USA. Proceedings of the International Congress of Speleology, 8th Meeting, Bowling Green I\&II, 196-199.

Dlugokencky, E.J., Houweling, S., Bruhwiler, L., Masarie, K.A., Lang, P.M., Miller, J.B., Tans, P.P., 2003. Atmospheric methane levels off: Temporary pause or a new steady state? Geophysical Research Letters 30(19, 1992). http://dx.doi.org/10.1029/2003GL018126

Dlugokencky, E.J., Nisbet, E.G., Fisher, R., Lowry, D., 2011. Global atmospheric methane: budget, changes and dangers. Philosophical Transactions of the Royal Society A 369, 2058-2072. http://dx.doi.org/10.1098/rsta.2010.0341

Engel, A.S., Porter, M.L., Stern, L.A., Quinlan, S., Bennet, P.C., 2004. Bacterial diversity and ecosystem function of filamentous microbial mats from aphotic (cave) sulfidic springs dominated by chemolithoautotrophic "Epsilonproteobacteria". FEMS Microbiology Ecology 51, 31-53. http://dx.doi.org/10.1016/j.femsec.2004.07.004 
Etiope, G., Sherwood Lollar, B., 2013. Abiotic methane on earth. Reviews of Geophysics 51, 276-299. http://dx.doi.org/10.1002/rog.20011

Feisthauer, S., Vogt, C., Modrzynski, J., Szlenkier, M., Krüger, M., Siegert, M., Richnow, H.H., 2011. Different types of methane monooxygenases produce similar carbon and hydrogen isotope fraction patterns during methane oxidation. Geochimica et Cosmochimica Acta 75, 1173-1184. http://dx.doi.org/10.1016/j.gca.2010.12.006

Fernandez-Cortes, A., Cuezva, S., Alvarez-Gallego, M., Garcia-Anton, E., Pla, C., Benavente, D., Jurado V., Saiz-Jimenez, C., Sanchez-Moral, S., 2015. Subterranean atmospheres may act as daily methane sinks. Nature Communications 6(7003). http://dx.doi.org/10.1038/ncomms8003

Garcia-Anton, E., Cuezva, S., Fernandez-Cortes, A., Benavente, D., Sanchez-Moral, S., 2014. Main drivers of diffusive and advective processes of $\mathrm{CO}_{2}$-gas exchange between a shallow vadose zone and the atmosphere. International Journal of Greenhouse Gas Control 21, 113-129. http://dx.doi.org/10.1016/j.ijggc.2013.12.006

Gregorič, A., Zidanšek, A., Vaupotič, J., 2011. Dependence of radon levels in Postojna Cave on outside air temperature. Natural Hazards and Earth System Sciences 11, 1523-1528. http://dx.doi.org/ 10.5194/nhess-11-1523-2011

Gregorič, A., Vaupotič, J., Gabrovšek, F., 2013. Reasons for large fluctuation of radon and $\mathrm{CO}_{2}$ levels in a dead-end passage of a karst cave (Postojna Cave, Slovenia). Natural Hazards and Earth System Sciences 13, 287-297. http://dx.doi.org/10.5194/nhess-13-287-2013 
Gregorič, A., Vaupotič, J., Šebela, S., 2014. The role of cave ventilation in governing cave air temperature and radon levels (Postojna Cave, Slovenia). International Journal of Climatology 34, 1488-1500. http://dx.doi.org/10.1002/joc.3778

Hutchens, E., Radajewski, S., Dumont, M.G., McDonald, I.R., Murrell, J.C., 2004. Analysis of methanotrophic bacteria in Movile Cave by stable isotope probing. Environmental Microbiology 6(2), 111-120. http://dx.doi.org/10.1046/j.1462-2920.2003.00543.x

Jones, D.S., Albrecht, H.L., Dawson, K.S., Schaperdoth, I., Freeman, K.H., Pi, Y., Pearson, A., Macalady, J.L., 2012. Community genomic analysis of an extremely acidophilic sulfuroxidizing biofilm. The ISME Journal 6, 158-170.

http://dx.doi.org/10.1038/ismej.2011.75

Kirschke, S., Bousquet, P., Ciais, P., Saunois, M., Canadell, J.G., Dlugokencky, E.J., Bergamaschi, P., Bergmann, D., Blake, D.R., Bruhwiler, L., Cameron-Smith, P., Castaldi, S., Chevallier, F., Feng, L., Fraser, A., Fraser, P.J., Heimann, M., Hodson, E.L., Houweling, S., Josse, B., Krummel, P.B., Lamarque, J.-F., Langenfelds, R. L., Le Quéré, C., Naik, V., O’Doherty, S., Palmer, P.I., Pison, I., Plummer, D., Poulter, B., Prinn, R.G., Rigby, M., Ringeval, B., Santini, M., Schmidt, M., Schindell, D.T., Simpson, I.J., Spahni, R., Steele, L.P., Strode, S.A., Sudo, K., Szopa, S., van der Werf, G.R., Voulgarakis, A., van Weele, M., Weiss, R.F., Williams, J.E., Zeng, G., 2013. Three decades of global methane sources and sinks. Nature Geoscience 6, 812-823. http://dx.doi.org/10.1038/NGEO1955

Kowalczk, A.J., Froelich, P.N., 2010. Cave air ventilation and $\mathrm{CO}_{2}$ outgassing by radon-222 monitoring: How fast do caves breathe? Earth and Planetary Science Letters 289, 209219. http://dx.doi.org/10.1016/j.epsl.2009.11.010 
Lakey, B., Krothe, N.C., 1996. Stable isotopic variation of storm discharge from a perennial karst spring, Indiana. Water Resources Research 32(3), 721-731.

Mattey, D.P., Fairchild, I.J., Atkinson, T.C., Latin, J.-P., Ainsworth, M., Durell, R., 2010. Seasonal microclimate control of calcite fabrics, stable isotopes and trace elements in modern speleothem from St. Michaels Cave, Gibraltar. In Tufas and Speleothems: Unravelling the Microbial and Physical Controls (Pedley, H.M., Rogerson, M. eds.), Geological Society, London, Special Publications 336, 323-344. http://dx.doi.org/10.1144/SP336.17

Mattey, D.P., Fisher, R., Atkinson, T.C., Latin, J.-P., Durrell, R., Ainsworth, M., Lowry, D., Fairchild, I.J., 2013. Methane in underground air in Gibraltar karst. Earth and Planetary Science Letters 374, 71-80. http://dx.doi.org/10.1016/j.epsl.2013.05.011

McDonough, L.K., Iverach, C.P., Beckman, S., Manfield, M., Rau, G.C., Baker, A., Kelly, B.F.J., 2016. Spatial variability of cave-air carbon dioxide and methane concentrations and isotopic compositions in a semi-arid karst environment. Environmental Earth Sciences 75, 700. http://dx.doi.org/10.1007/s12665-016-5497-5

Miller, J.B., Mack, K.A., Dissly, R., White, J.W.C., Dlugokencky, E.J., Tans, P.P., 2002. Development of analytical methods and measurements of ${ }^{13} \mathrm{C} /{ }^{12} \mathrm{C}$ in atmospheric $\mathrm{CH}_{4}$ from the NOAA Climate Monitoring and Diagnostics Laboratory Global Air Sampling Network. Journal of Geophysical Research: Atmospheres 107(D13), ACH 11-1-ACH 11-15. http://dx.doi.org/10.1029/2001JD000630 
Naik, V., Voulgarakis, A., Fiore, A.M., Horowitz, L.W., Lamarque, J.-F., Lin., M., Prather, M.J., Young, P.J., Bergmann, D., Cameron-Smith, P.J., Cionni, I., Collins, W.J., Dalsøren, S.B., Doherty, R., Eyring, V., Faluvegi, G., Folberth, G.A., Josse, B., Lee, Y.H., MacKenzie, I.A., Nagashima, T., van Noije, T.P.C., Plummer, D.A., Righi, M., Rumbold, S.T., Skeie, R., Shindell, D.T., Stevenson, D.S., Strode, S., Sudo, K., Szopa, S., Zeng, G., 2013. Preindustrial to present-day changes in tropospheric hydroxyl radical and methane lifetime from the Atmospheric Chemistry and Climate Model Intercomparison Project (ACCMIP). Atmospheric Chemistry and Physics 13, 52775298. https://dx.doi.org/10.5194/acp-13-5277-2013

NCEI, National Center for Enivronmental Research, Asheville, NC. http://www.ncdc.noaa.gov/qclcd/QCLCD?prior=N

Ortiz, M., Neilson, J.W., Nelson, W.M., Legatzki, A., Byrne, A., Yu, Y., Wing, R.A., Soderlund, C.A., Pryor, B.M., Pierson III., L.S., Maier, R.M., 2013. Profiling bacterial diversity and taxonomic composition on speleothem surfaces in Kartchner Caverns, AZ. Microbial Ecology 65, 371-383. http://dx.doi.org/10.1007/s00248-012-0143-6

Palmer, A.N, 1991. Origin and morphology of limestone caves. Geological Society of America Bulletin 103, 1-21. http://dx.doi.org/10.1130/00167606(1991)103<0001:OAMOLC>2.3.CO;2

Pašić, L., Kovče, B., Sket, B., Herzog-Velikonja, B., 2010. Diversity of microbial communities colonizing the walls of a karstic cave in Slovenia. FEMS Microbiology Ecology 71, 5060. http://dx.doi.org/10.1111/j.1574-6941.2009.00789.x 
Peyraube, N., Lastennet, R., Denis, A., Malaurent, P., 2013. Estimation of epikarst air $P_{\mathrm{CO}_{2}}$ using measurements of water $\delta^{13} \mathrm{C}_{\mathrm{TDIC}}$, cave air $P_{\mathrm{CO}_{2}}$ and $\delta^{13} \mathrm{C}_{\mathrm{CO}_{2}}$. Geochimica et Cosmochimica Acta 118, 1-17. http://dx.doi.org/10.1016/j.gca.2013.03.046

Porca, E., Jurado, V., Žgur-Bertok, D., Saiz-Jimenez, C., Pašić, L., 2012. Comparative analysis of yellow microbial communities growing on the walls of geographically distinct caves indicates a common core of microorganisms involved in their formation. FEMS Microbiology Ecology 81, 255-266. http://dx.doi.org/10.1111/j.1574-6941.2012.01383.x

Sachs, T., Wille, C., Boike, J., Kutzbach, L., 2008. Environmental controls on ecosystem-scale $\mathrm{CH}_{4}$ emission from polygonal tundra in the Lena River Delta, Siberia. Journal of Geophysical Research: Biogeosciences 113, G00A03. http://dx.doi.org/10.1029/2007JG000505

Sarbu, S.M., Kane, T.C., Kinkle, B.K., 1996. A chemoautotrophically based cave ecosystem. Science 272(5270), 1953-1955. http://dx.doi.org/10.1126/science.272.5270.1953

Saueressig, G., Crowley, J.N., Bergamaschi, P., Brühl, C., Brennikmeijer, C.A.M., Fischer, H. 2001. Carbon 13 and D kinetic isotope effects in the reactions of $\mathrm{CH}_{4}$ with $\mathrm{O}\left({ }^{1} D\right)$ and $\mathrm{OH}$ : New laboratory measurements and their implications for the isotopic composition of stratospheric methane. Journal of Geophysical Research 106(D19), 23127-23138. http://dx.doi.org/10.1029/2000JD000120

Spötl, C., Fairchild, I.J., Tooth, A.F., 2005. Cave air control on dripwater geochemistry, Obir Caves (Austria): Implications for speleothem deposition in dynamically ventilated caves. Geochimica et Cosmochimica Acta 69(10), 2451-2468. http://dx.doi.org/10.1016/j.gca.2004.12.009 
Tagesson, T., Mölder, M., Mastepanov, M., Sigsgaard, C., Tamstorf, M.P., Lund, M., Falk, J. M., Lindroth, A., Christensen, T.R., Ström, L., 2012. Land-atmosphere exchange of methane from soil thawing to soil freezing in a high-Arctic wet tundra ecosystem. Global Change Biology 18, 1928-1940. http://dx.doi.org/10.1111/j.13652486.2012.02647.x

Tazaz, A.M., Bebout, B.M., Kelley, C.A., Poole, J., Chanton, J.P., 2013. Redefining the isotopic boundaries of biogenic methane: Methane from endoevaporites. Icarus 224(2), 268-275. http://dx.doi.org/10.1016/j.icarus.2012.06.008

Townsend-Small, A., Tyler, S.C., Pataki, D.E., Xu, X., Christensen, L.E., 2012. Isotopic measurements of atmospheric methane in Los Angeles, California, USA: Influence of “fugitive” fossil fuel emissions. Journal of Geophysical Research 117, D07308.

Tu, K.P., Brooks, P.D., Dawson, T.E., 2001. Using septum-capped vials with continuous-flow isotope ratio mass spectrometric analysis of atmospheric $\mathrm{CO}_{2}$ for Keeling plot applications. Rapid Communications in Mass Spectrometry 15, 952-956. http://dx.doi.org/10.1002/rcm.320

U.S. EPA, United States Environmental Protection Agency, 2010. Methane and nitrous oxide emissions from natural sources. Office of Atmospheric Programs (6207J), Washington, DC 20460. EPA 430-R-10-001.

Webster, K.D., White, J.R., Pratt, L.M., 2015. Ground-level concentrations of atmospheric methane in southwest Greenland evaluated using open-path laser spectroscopy and cavity-enhanced absorption spectroscopy. Arctic, Antarctic, and Alpine Research 47(4), 599-609. http://dx.doi.org/10.1657/AAAR0014-051 
Whiticar, M.J., 1999. Carbon and hydrogen isotope systematics of bacterial formation and oxidation of methane. Chemical Geology 161, 291-314. http://dx.doi.org/10.1016/S0009-2541(99)00092-3

Figure 1. Location of Buckner Cave in Southern Indiana (A) and the USA (B). Satellite image from Google Maps.

Figure 2. Simplified map of Buckner Cave showing the Main Entrance and sampling locations labeled by numbers. This map has been redrawn from the map of Buckner Cave published by the Richard Blenz Nature Conservancy in 2012. Small blue arrows indicate streams and their direction of flow.

Figure 3. Results from the first part of the study identifying broad scale airflow patterns in Buckner Cave. Date is represented as mm/yy on the horizontal axis. Notice that temperatures elevated air temperatures relative to the average temperature of Buckner Cave (A) corresponded to periods of high $\mathrm{CO}_{2}$ mole fractions in Buckner Cave (B). Summer airflow in Buckner Cave (vertical gray bars) was defined to encompass periods when the $\mathrm{CO}_{2}$ mole fraction was above 2000 ppm. Summer airflow coincided with daily low temperatures that were generally higher than the average cave temperature $\left(12.8^{\circ} \mathrm{C}\right)$ and lasted until the daily high temperature was generally colder than the average cave temperature. Air temperatures in (A) were measured at 
Monroe County Airport and were from the National Center for Environmental Information (NCEI). Errors bars in (B) are smaller than the data points.

Figure 4. Time series data collected during the 2013 - 2015 field campaign. Date is on the horizontal axis as mm/yy. Vertical gray bars represent times of summer airflow and vertical white bars correspond to times of winter airflow. Elevated air temperatures relative to the average temperature of Buckner Cave (A) corresponded to high and low $\mathrm{CO}_{2}$ mole fractions (B), respectively. More negative $\delta^{13} \mathrm{C}_{\mathrm{CO}_{2}}$ values were observed during summer airflow relative to winter airflow (C). $\mathrm{CH}_{4}$ mole fractions in Buckner Cave (D) were negatively correlated to the outside air temperature. More variable $\delta^{13} \mathrm{C}_{\mathrm{CH}_{4}}(\mathrm{E})$ and $\delta^{2} \mathrm{H}_{\mathrm{CH}_{4}}(\mathrm{~F})$ values were observed during summer airflow compared to winter airflow. A lack of error bars indicates that the analytical uncertainty was smaller than the plotted data symbol. Air Temperatures in (A) were measured at Monroe County Airport and were retrieved from the National Center for Environmental Information (NCEI).

Figure 5: Results from the $\mathrm{CH}_{4}$ and $\mathrm{SF}_{6}$ addition experiment to capture a change in cave air $\mathrm{CH}_{4}$ mole fraction in Buckner Cave. Baseline $\mathrm{CH}_{4}$ mole fractions decrease after a reversal in airflow at 19:45. $\mathrm{CH}_{4}(\mathrm{~A})$ and $\mathrm{SF}_{6}$ spikes $(\mathrm{B})$ at 18:27, 19:20, and 20:10 show that $\mathrm{CH}_{4}$ and $\mathrm{SF}_{6}$ exhibited the same behavior in Buckner Cave. $\mathrm{CH}_{4}$ mole fractions returned to previous base line mole fractions as $\mathrm{SF}_{6}$ mole fractions decreased to $4 \mathrm{ppb}$. If error bars are not visible they are smaller than the data points. 
Figure 6: The $\mathrm{CH}_{4}$ mole fraction in the air of Buckner Cave decreases as the distance from the main entrance increases. The statistics show that the $\mathrm{CH}_{4}$ mole fraction in interior rooms is lower than the $\mathrm{CH}_{4}$ mole fraction in exterior rooms. The uncertainty associated with all points is $\pm 0.1 \mathrm{ppm}$.

Figure 7: The $\delta^{13} \mathrm{C}_{\mathrm{CO}_{2}}$ vs. $\mathrm{CO}_{2}$ mole fraction in Buckner Cave air. The data suggest that atmospheric $\mathrm{CO}_{2}$ is mixing with isotopic endmembers between -35 and $-20 \%$. Summer air shows the influence of a more positive end member and winter air shows the influence a more negative end member. Soil $\mathrm{CO}_{2}$ is modeled with a $\delta^{13} \mathrm{C}_{\mathrm{CO}_{2}}$ value of $-24 \%$. The color scheme follows that of Figure 4 . Site $1=$ light blue, Site $2=$ dark red, Site $3=$ black, Site $4=$ red, Site 5 $=$ dark blue. If error bars are not visible, they are smaller than the data points.

Figure 8: $\mathrm{CH}_{4}$ mole fraction vs. $\delta^{13} \mathrm{C}_{\mathrm{CH}_{4}}$ observed in Buckner Cave air. The expected isotopic trend (dotted line) along methanotrophic depletion of atmospheric $\mathrm{CH}_{4}$ was calculated assuming a starting $\mathrm{CH}_{4}$ mole fraction of $1.8 \mathrm{ppm}$, a $\delta^{13} \mathrm{C}_{\mathrm{CH}_{4}}$ value of $-47 \%$, and a fractionation factor of 1.018 (Barker and Fritz, 1981; Coleman et al., 1981; Feisthauer et al., 2013). $\cdot$ OH oxidation is modeled with a fractionation factor of 1.0039 (Saueressig et al., 2001). 
Figure 9: $\mathrm{CH}_{4}$ mole fraction vs $\delta^{2} \mathrm{H}_{\mathrm{CH}_{4}}$ values observed in Buckner Cave. The light gray dotted line represents the expected methanotrophic fractionation of an atmospheric methane (1.8 ppm, $-100 \%$ ) using a fractionation factor of 1.2413 (Coleman et al., 1981). $\cdot$ OH oxidation is modeled with a fractionation factor of 1.294 (Saueressig, et al., 2001). The discrepancy between the observed $\delta^{2} \mathrm{H}_{\mathrm{CH}_{4}}$ values and the predicted $\delta^{2} \mathrm{H}_{\mathrm{CH}_{4}}$ values of partially degraded atmospheric methane shows the existence of a source of ${ }^{2} \mathrm{H}$-depleted methane.

Figure 10: Stable isotopic composition of $\mathrm{CH}_{4}$ in Buckner Cave plotted in $\delta^{2} \mathrm{H}_{\mathrm{CH}_{4}}$ versus $\delta^{13} \mathrm{C}_{\mathrm{CH}_{4}}$ space. The dashed outlines in the figure represent most of the isotopic ranges of $\mathrm{CH}_{4}$ generate by thermogenic processes and acetate fermentation (Etiope and Sherwood Lollar, 2013). Methanotrophic oxidation is modeled with a slope of 8.5 and $\cdot \mathrm{OH}$ oxidation is modeled with a slope 75 (Saueressig et al., 2001; Feisthauer et al., 2011).

Supplemental 1: $\mathrm{CH}_{4}$ and $\mathrm{CO}_{2}$ mole fractions, collection dates, and analysis date for each site.

Supplemental 2: The stable isotopic compositions of $\mathrm{CH}_{4}$ and $\mathrm{CO}_{2}$, collection dates, and analysis date for each site. 

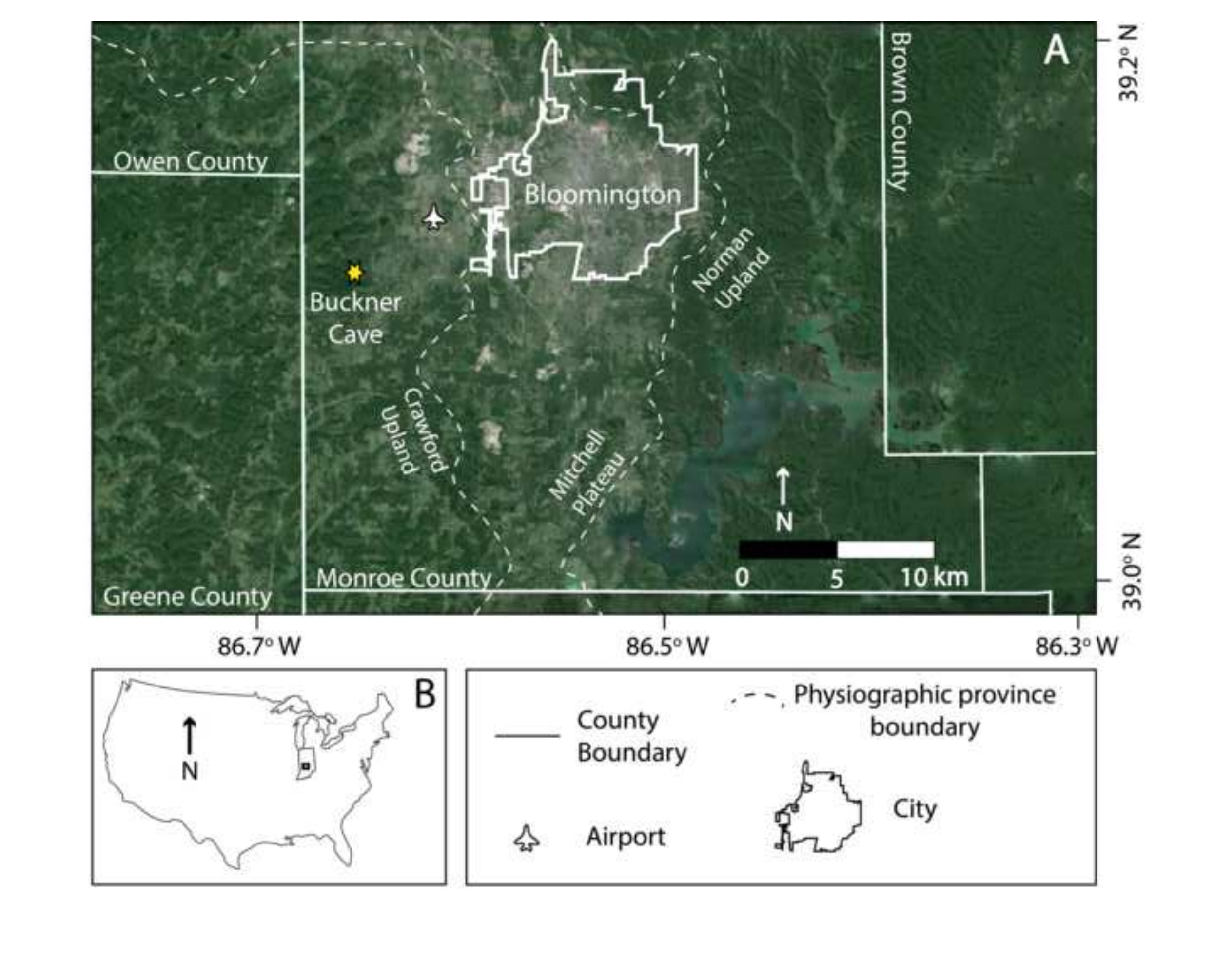


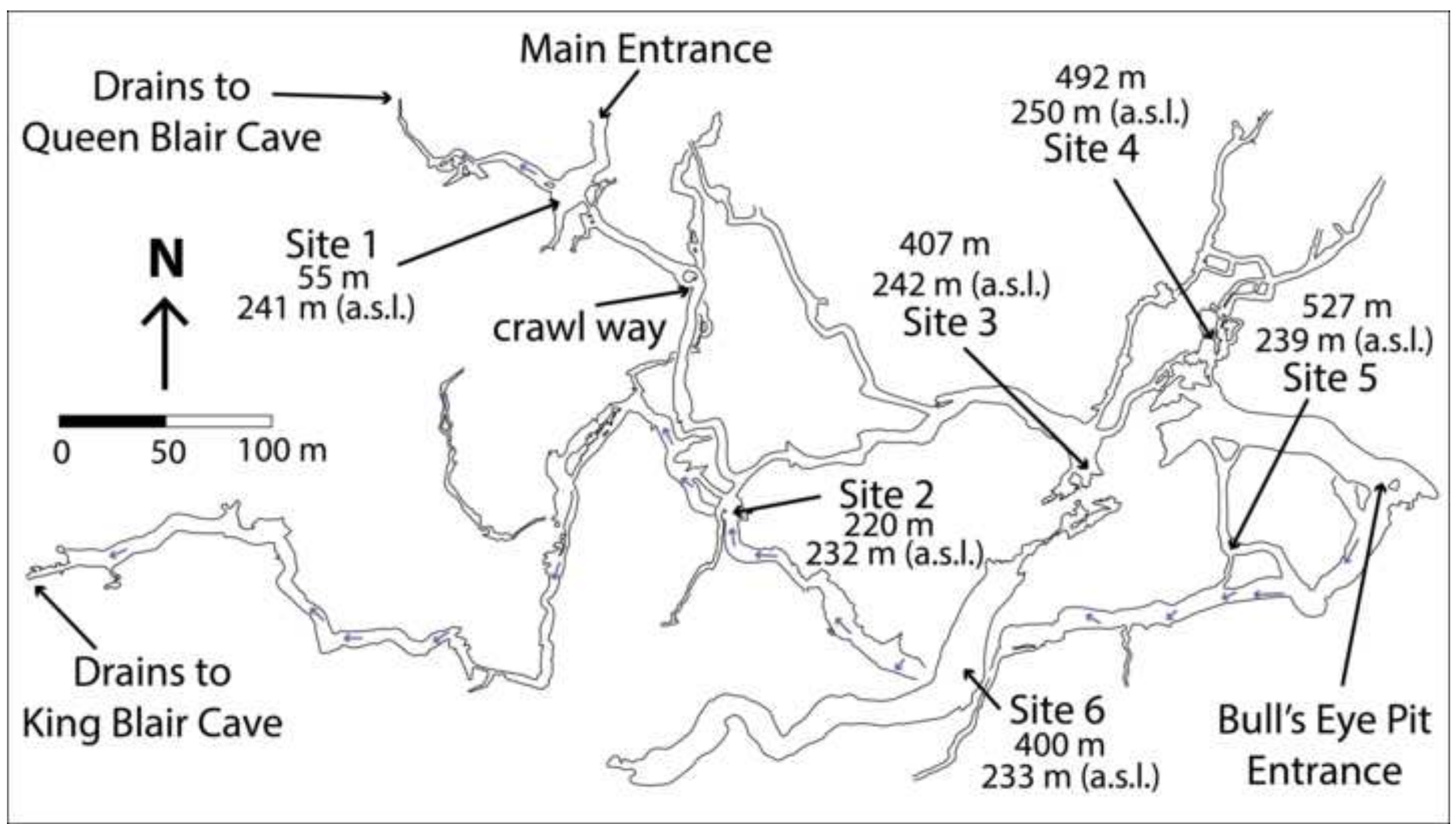




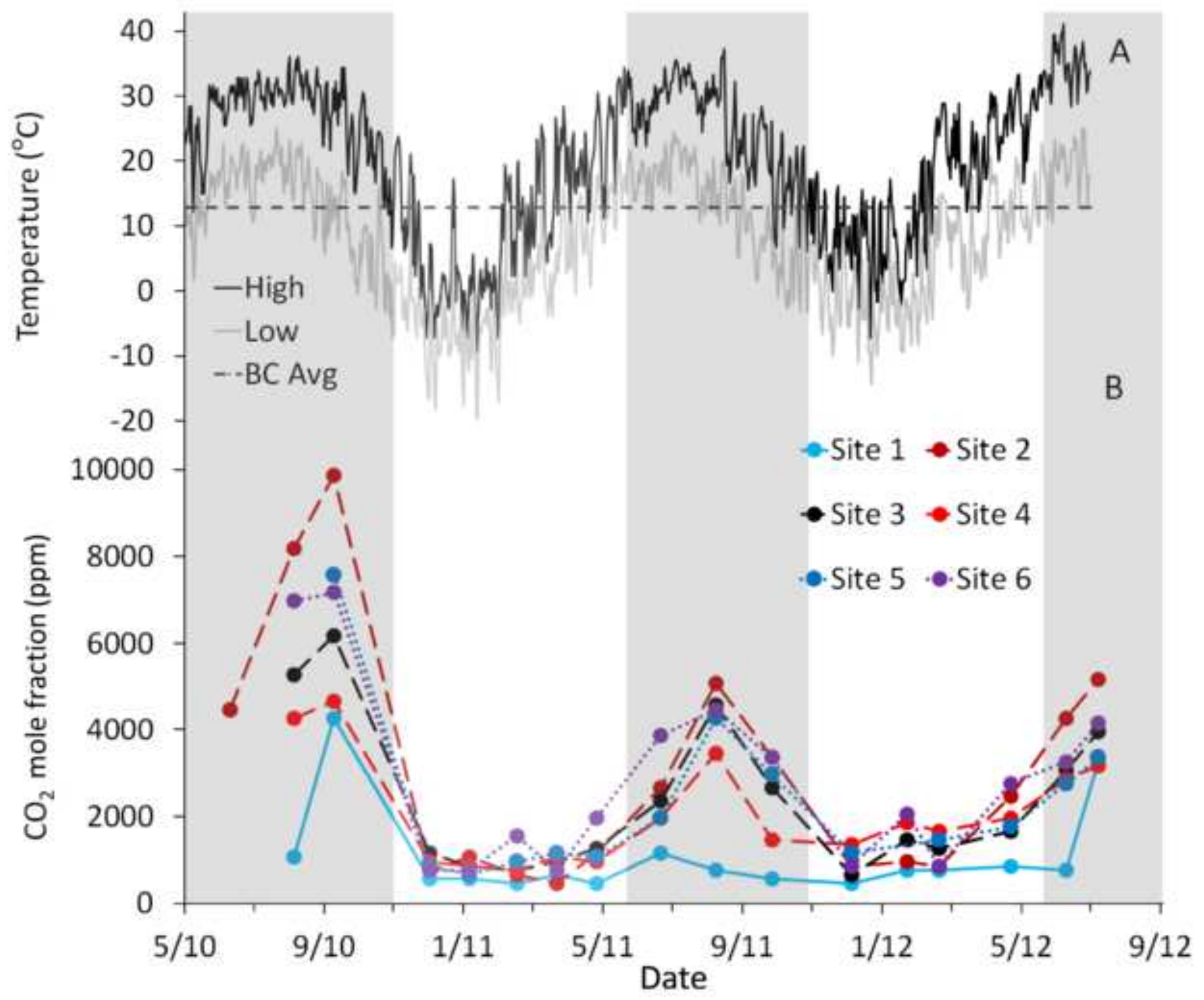



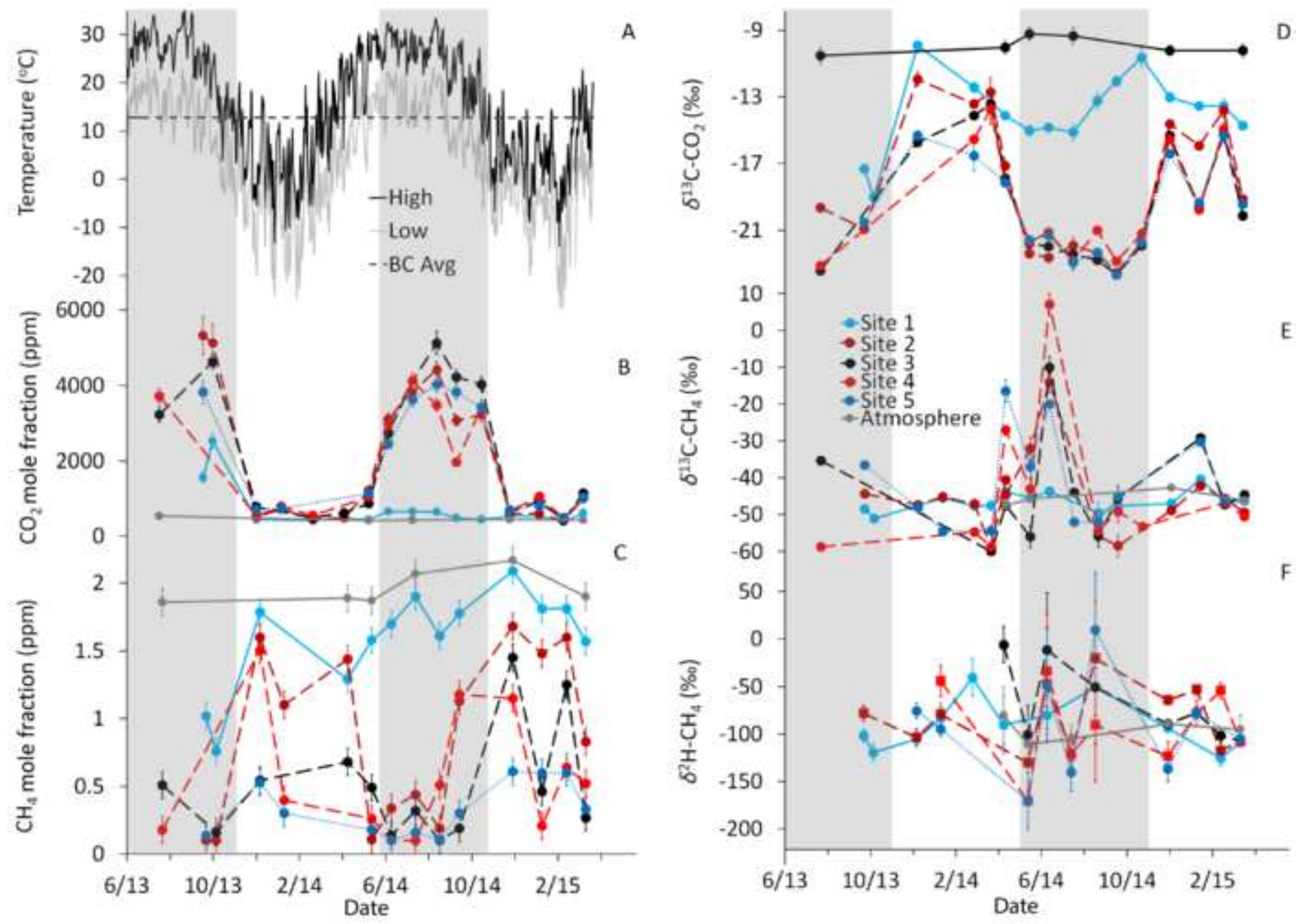


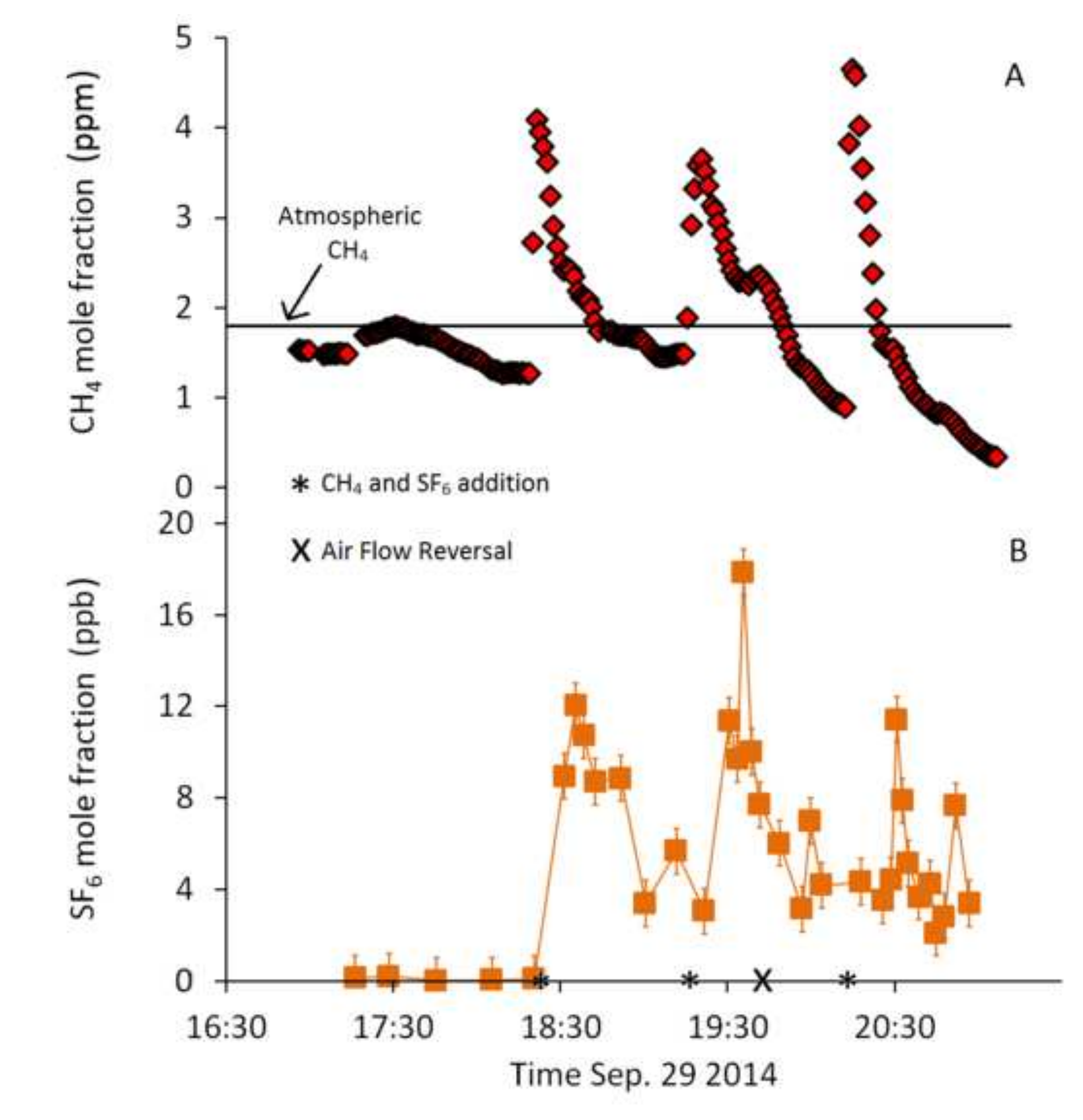

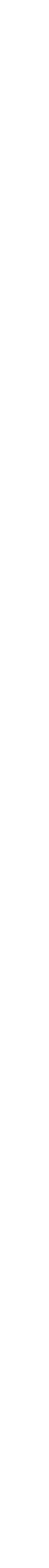

.
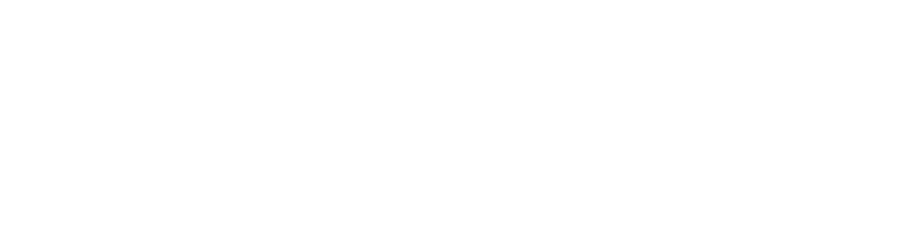

tr
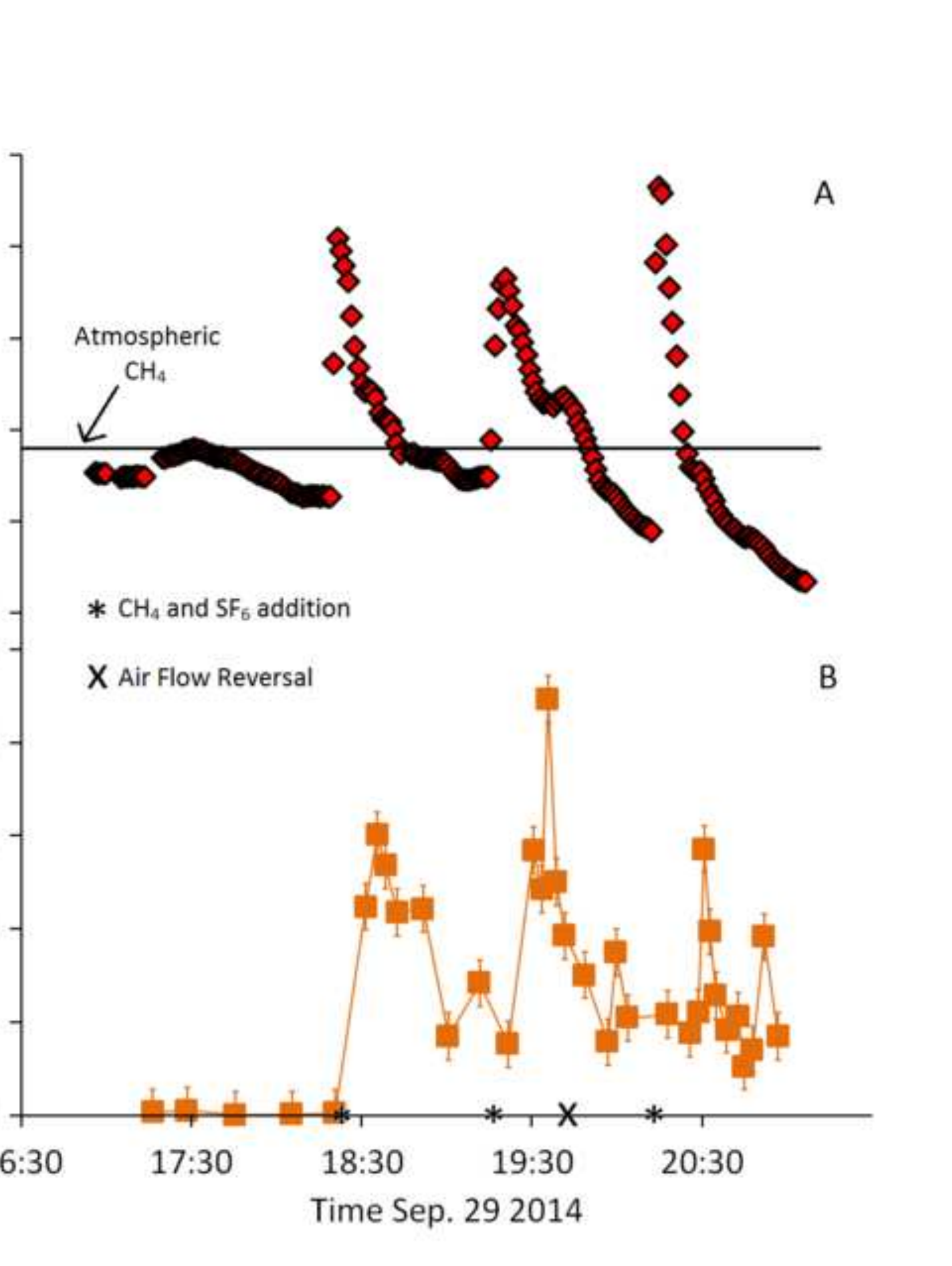


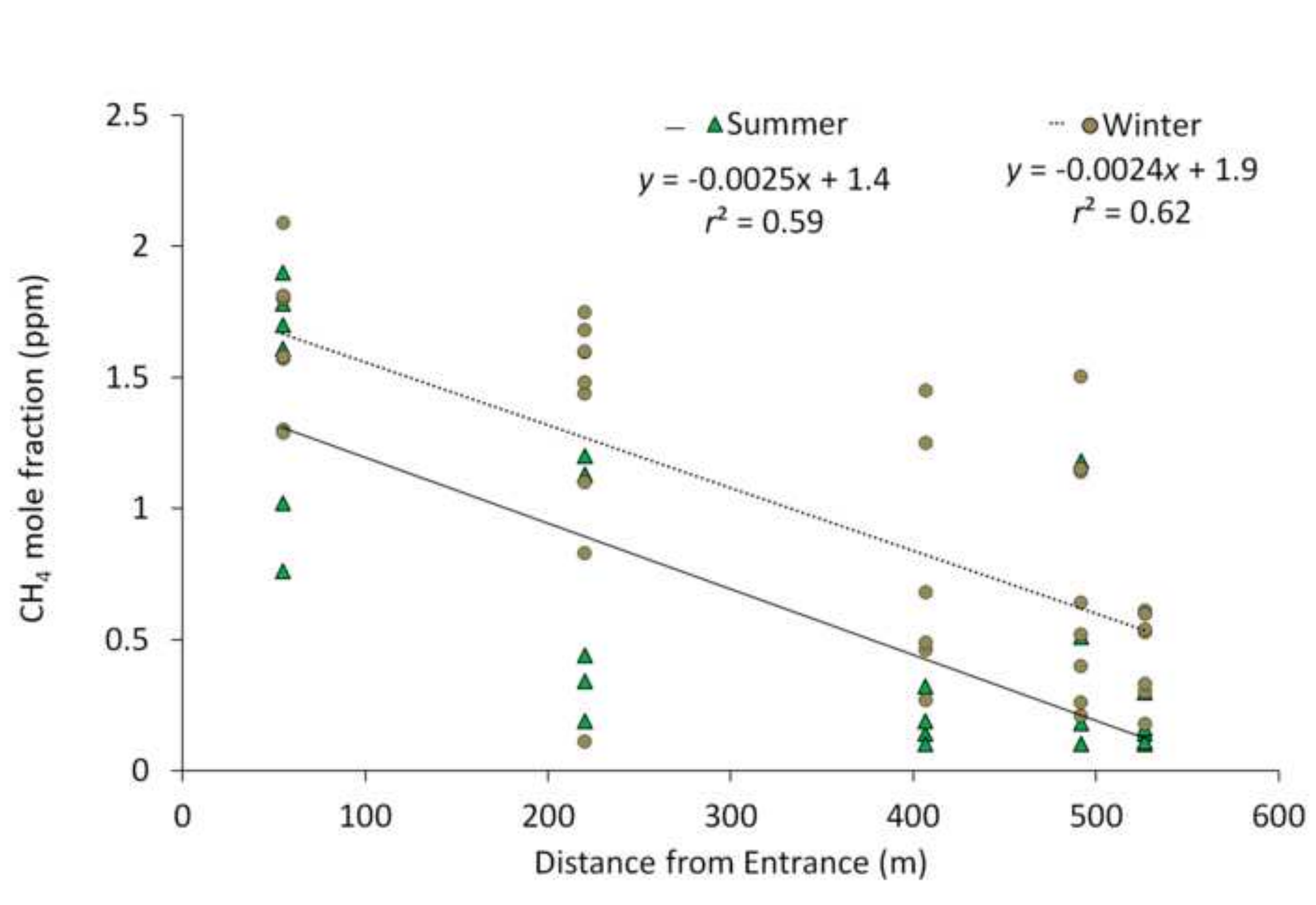

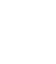

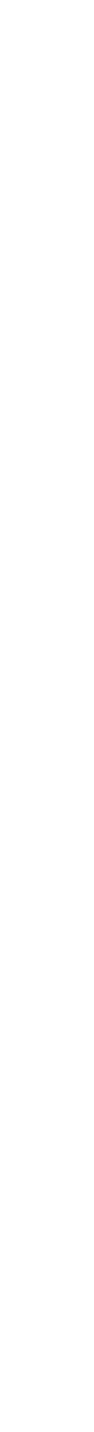

(

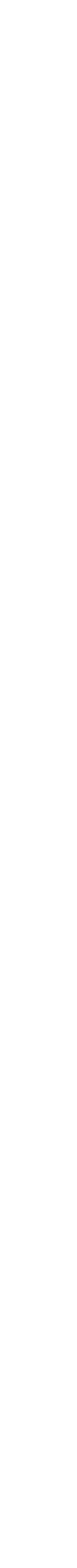




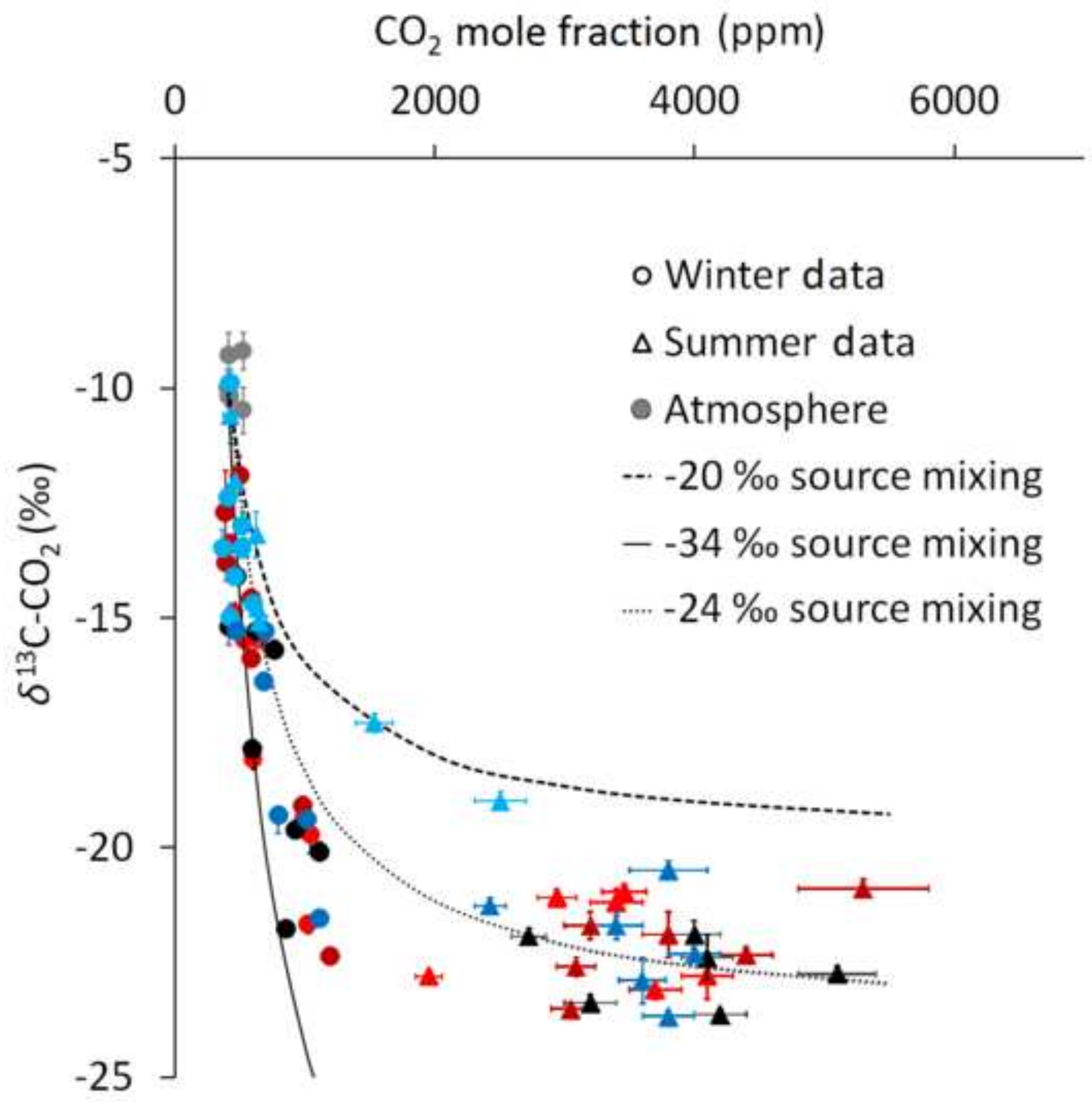

$\mathrm{CO}_{2}$ mole fraction (ppm)

- Winter data

$\Delta$ Summer data

- Atmosphere

-.. -20\% source mixing

$--34 \%$ source mixing

.... - $24 \%$ o source mixing

$-25$ 


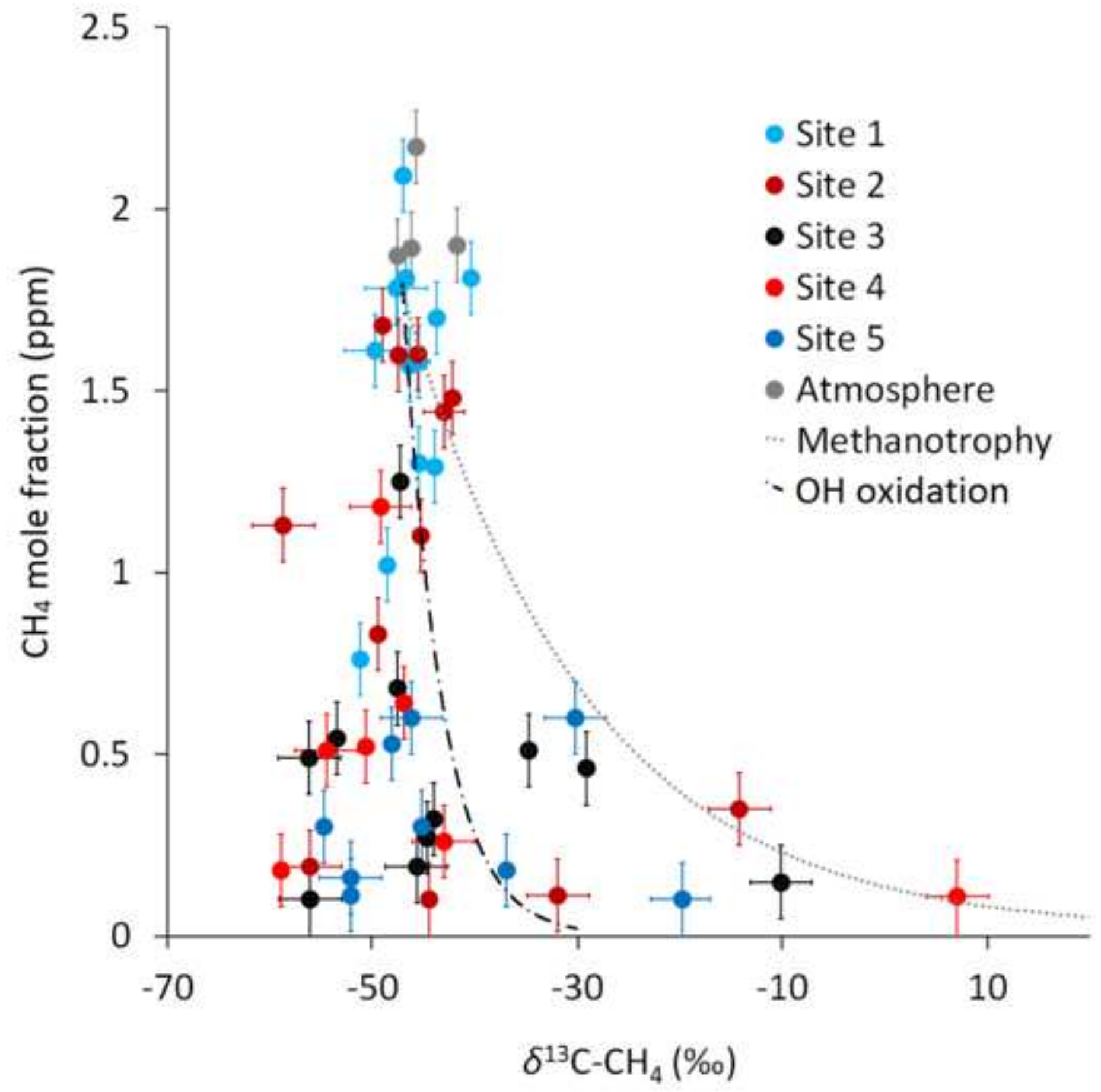




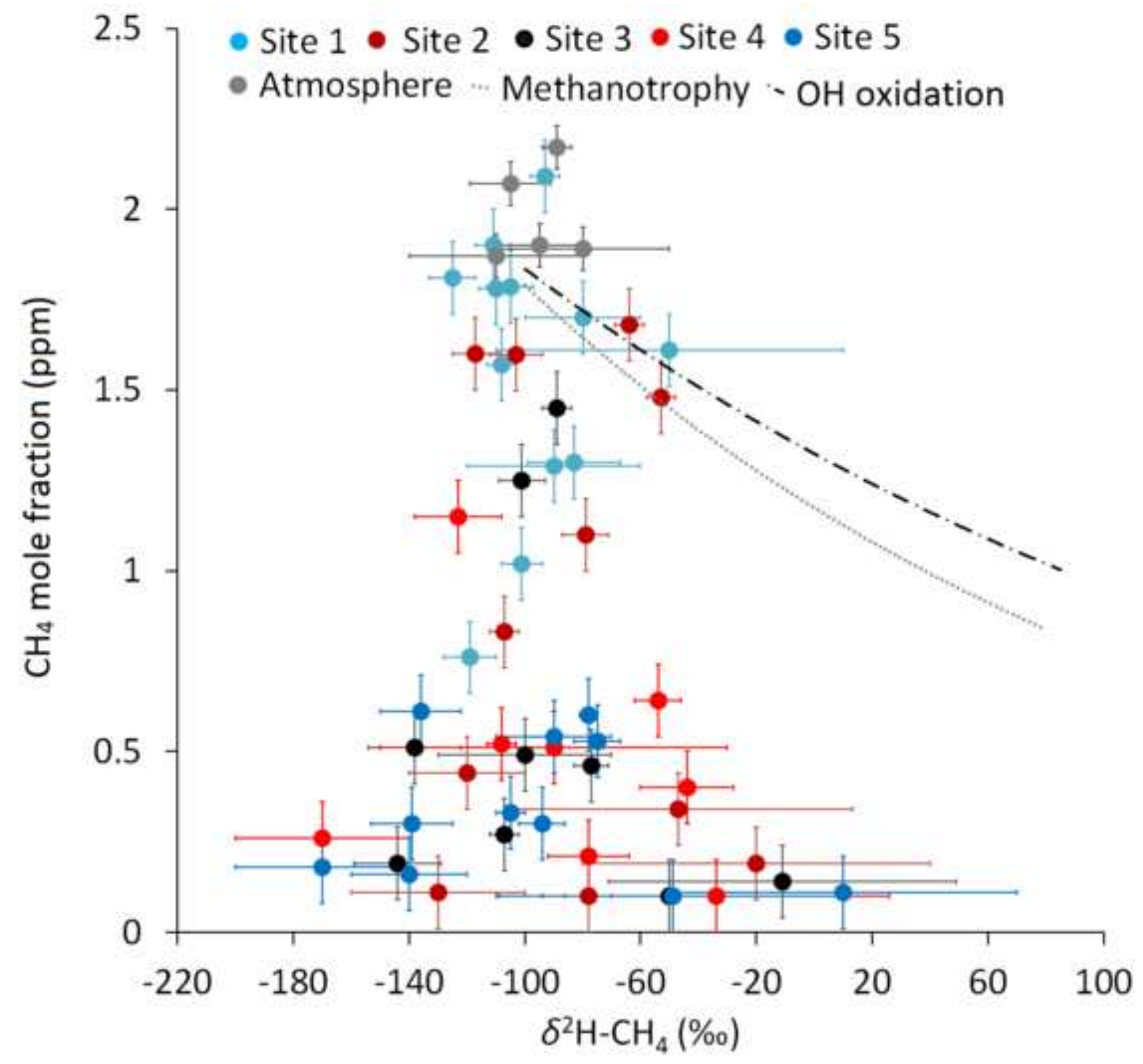




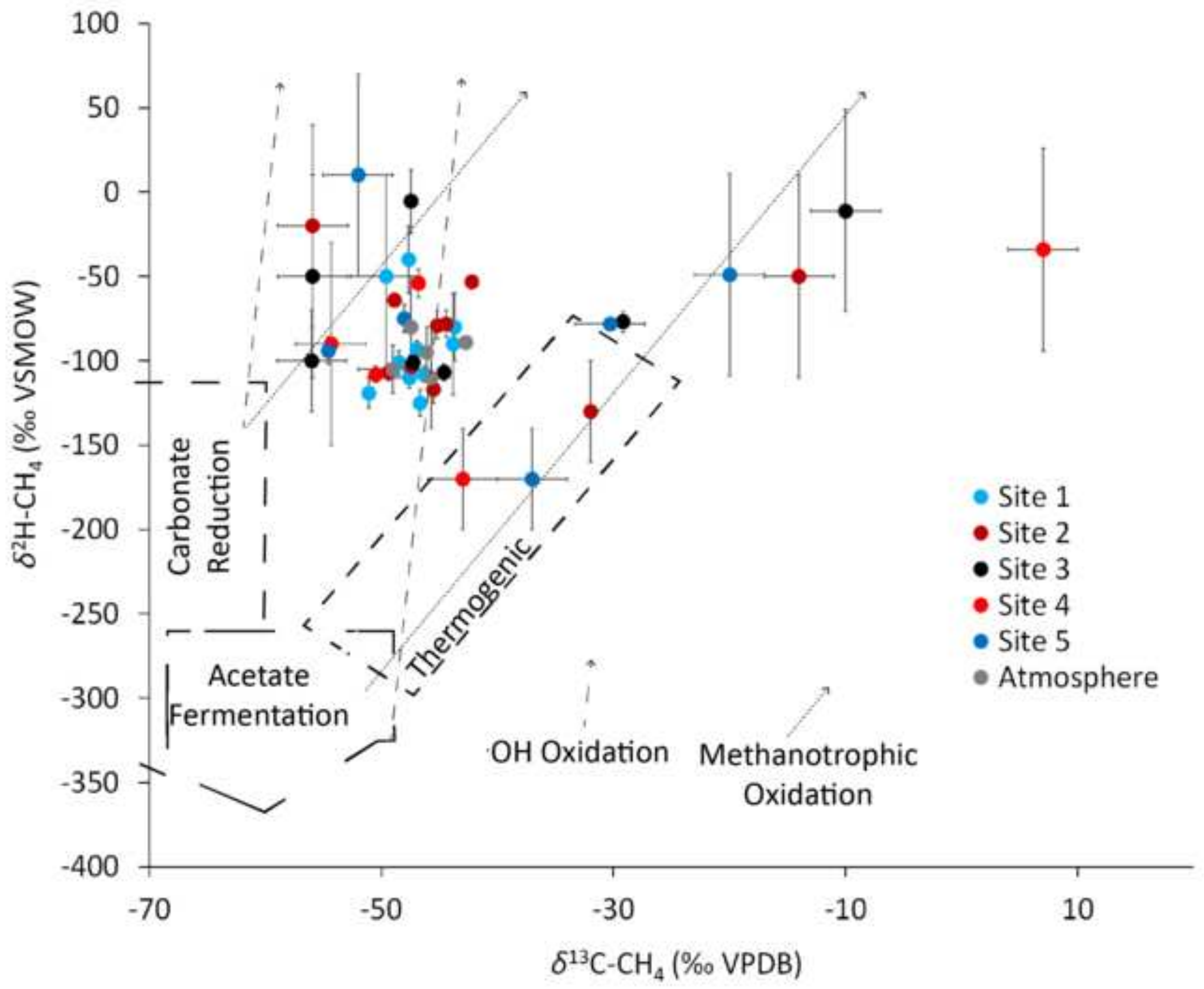

